\title{
Approaches to Inactivating Aflatoxins-A Review and Challenges
}

\author{
Kinga Kutasi ${ }^{1}$, Nina Recek ${ }^{1}{ }^{\oplus}$, Rok Zaplotnik ${ }^{1} \oplus$, Miran Mozetič ${ }^{1}{ }^{\oplus}$, Mitja Krajnc ${ }^{2}$, Peter Gselman ${ }^{3}$ \\ and Gregor Primc $1, *$ (i)
}

1 Department of Surface Engineering, Jozef Stefan Institute, Jamova Cesta 39, 1000 Ljubljana, Slovenia; kutasi.kinga@wigner.hu (K.K.); nina.recek@ijs.si (N.R.); rok.zaplotnik@ijs.si (R.Z.); miran.mozetic@ijs.si (M.M.)

2 Žipo Ltd., Šetarova 21, 2230 Lenart, Slovenia; mitja.krajnc@kgskrajnc.si

3 Interkorn Ltd., Gančani 94, 9231 Beltinci, Slovenia; peter.gselman@interkorn.si

* Correspondence: gregor.primc@ijs.si; Tel.: +386-14773672

Citation: Kutasi, K.; Recek, N.;

Zaplotnik, R.; Mozetič, M.; Krajnc, M.; Gselman, P.; Primc, G. Approaches to Inactivating Aflatoxins-A Review and Challenges. Int. J. Mol. Sci. 2021, 22, 13322. https://doi.org/10.3390/ ijms222413322

Academic Editors: Akikazu Sakudo and Yoshihito Yagyu

Received: 12 November 2021 Accepted: 9 December 2021 Published: 11 December 2021

Publisher's Note: MDPI stays neutral with regard to jurisdictional claims in published maps and institutional affiliations.

Copyright: (c) 2021 by the authors. Licensee MDPI, Basel, Switzerland. This article is an open access article distributed under the terms and conditions of the Creative Commons Attribution (CC BY) license (https:// creativecommons.org/licenses/by/ $4.0 /)$.

\begin{abstract}
According to the World Health Organization, the contamination of crops with aflatoxins poses a significant economic burden, estimated to affect $25 \%$ of global food crops. In the event that the contaminated food is processed, aflatoxins enter the general food supply and can cause serious diseases. Aflatoxins are distributed unevenly in food or feedstock, making eradicating them both a scientific and a technological challenge. Cooking, freezing, or pressurizing have little effect on aflatoxins. While chemical methods degrade toxins on the surface of contaminated food, the destruction inside entails a slow process. Physical techniques, such as irradiation with ultraviolet photons, pulses of extensive white radiation, and gaseous plasma, are promising; yet, the exact mechanisms concerning how these techniques degrade aflatoxins require further study. Correlations between the efficiency of such degradation and the processing parameters used by various authors are presented in this review. The lack of appropriate guidance while interpreting the observed results is a huge scientific challenge.
\end{abstract}

Keywords: mycotoxin; decontamination; gas-discharge plasma; ozonation; ammoniation; UV

\section{Introduction}

Whilst growing, field crops such as corn (Zea mays L.) are often exposed to pathogens (e.g., bacteria, fungi, viruses, and phytoplasmas), which can negatively impact both the yield and the quality. Ensuring a healthy population means it is necessary to be careful when fungi cause plant diseases. The saprophytic fungi that inhabit infected plant tissues can produce harmful substances known as mycotoxins.

Mycotoxins are secondary metabolites of filamentous fungi, dangerous to both humans and animals [1,2]. The most common mycotoxin-producing genera are Aspergillus, Fusarium, and Penicillium. The family of toxins produced by the fungi Aspergillus flavus and Aspergillius parasiticus pose the greatest danger to animal and human health. Aspergillus flavus is considered to be the most frequent source of aflatoxins in crops. As seed-inhabiting fungi, Aspergillus parasiticus can contaminate a wide variety of crops, either before harvesting in the field or after harvest while being handled and processed. Naturally occurring aflatoxins are the aflatoxin $\mathrm{B}_{1}\left(\mathrm{AFB}_{1}\right)$, the most potent carcinogenic agent known, and the aflatoxins $B_{2}, G_{1}$, and $G_{2}$ (aflatoxins $B_{2}$ and $G_{2}$ are dihydroxylated derivatives of $B_{1}$ and $G_{1}$ ) [3]. Aflatoxins can enter the human food chain directly through the consumption of infected crops/cereals, oilseeds, nuts, or spices or indirectly, when infected crops are fed to animals. The toxins can also be transferred into animal products such as milk, eggs, and meat. For example, the aflatoxins $M_{1}$ and $M_{2}$, which are hydroxylated derivatives of $B_{1}$ and $B_{2}$, can be found in the milk of cows fed with contaminated feed [4,5]. Aflatoxins were found to increase the risk of several diseases, such as liver and lung cancer with exposure to $\mathrm{AFB}_{1}$-contaminated grain dust and gastrointestinal cancer following the consumption of 
contaminated food [2]. Aflatoxins may be present in various food and feed crops, such as corn, wheat, rice, peanuts, Brazil nuts, pistachio nuts, red chili, peppers, almonds, cattle feed, poultry feed, and many more [6].

\section{Characteristics of Aflatoxins and Detoxification Methods}

\subsection{Toxicity and Properties}

The extent of the mycotoxins' toxicity and carcinogenicity is determined by the metabolites the mycotoxins are converted into, which can bind to critical cellular macromolecules. Aflatoxins are a family of compounds generally classified as difuranocoumarins. Inactive in their basic form, aflatoxins become carcinogenic upon biotransformation, producing metabolites capable of reacting with macromolecules. The metabolism of aflatoxins and the methods to modulate the metabolism are presented by Guengerich et al. [7]. Aflatoxin derivatives covalently bind to macromolecules through the unsaturated furan ring, leading to epoxidation (i.e., oxidation of the furan ring). $\mathrm{AFB}_{1}$ is converted into the reactive 8 , 9-exoepoxide and 8,9-endo-epoxide, with the exo-epoxide being the toxic species responsible for the $\mathrm{AFB}_{1}$ genotoxic properties [8], which bind to deoxyribonucleic acid (DNA) to form the predominant 8,9-dihydro-8- (N7-guanyl)-9-hydroxy- $\mathrm{AFB}_{1}\left(\mathrm{AFB}_{1}-\mathrm{N} 7-\mathrm{Gua}\right)$ adduct [9], as also detailed in [7]. Upon the adduct forming, the cell starts to become a tumor cell. It was also suggested that $\mathrm{AFB}_{1}$ induces reactive oxygen species (ROS) and thus oxidative stress, which activates mitochondrial ROS-dependent signal pathways, inducing apoptosis through the mitochondrial signal pathway [10].

The properties of aflatoxins were reviewed by Quadri et al. [11]. Aflatoxins are slightly soluble in water, insoluble in non-polar solvents, and freely soluble in polar organic solvents. They have strong thermal stability and remain stable even at temperatures above $100{ }^{\circ} \mathrm{C}$, preventing them from thermally degrading during food manufacturing, such as while pasteurizing milk and dairy products $[5,12]$. Significant decontamination was reported only when heating or roasting at temperatures of $150{ }^{\circ} \mathrm{C}$ or higher [13]. Aflatoxins are unstable in ultraviolet (UV) light in the presence of oxygen, in extreme $\mathrm{pH}$ conditions, such as $\mathrm{pH}<3$ or $>10$, and in the presence of oxidizing agents. In addition, the lactone ring of the coumarin structure is susceptible to alkaline hydrolysis, ammonia, and hypochlorite. These properties have led to the development of different decontamination methods, depicted schematically in Figure 1, which can significantly reduce the amount of mycotoxins in seeds and crops [14].

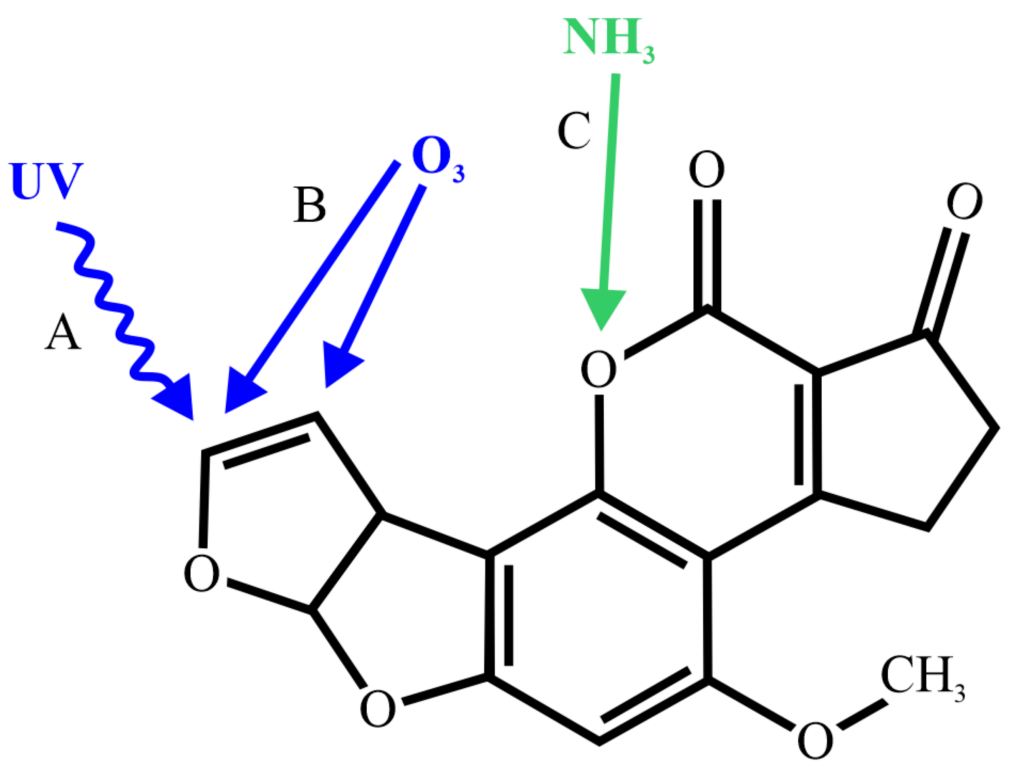

Figure 1. Schematic of $\mathrm{AFB}_{1}$ showing the sites of reactivity for three inactivation methods: (A) UV light; (B) ozone; and (C) ammonia. For each inactivation method, the reactivity site is specifically marked. 


\subsection{UV Radiation and Pulsed Light Treatment}

The study of light-induced mycotoxin decontamination dates back to the 1980s [15] and recently includes more thorough investigations. The photo-degradation of aflatoxin $B_{1}$ is schematically presented in Figure 2 and was recently studied in a water solution by Liu et al. [16]. Water solutions of various $\mathrm{AFB}_{1}$ concentrations were irradiated at $4{ }^{\circ} \mathrm{C}$ with an ultraviolet lamp using different intensities. Total degradation of $\mathrm{AFB}_{1}$ was obtained with treatments of $60 \mathrm{~min}, 80 \mathrm{~min}$, and $100 \mathrm{~min}$ while applying intensities of $800 \mu \mathrm{W} / \mathrm{cm}^{2}, 400 \mu \mathrm{W} / \mathrm{cm}^{2}$, and $200 \mu \mathrm{W} / \mathrm{cm}^{2}$, respectively. Three degradation products were identified, i.e., $\mathrm{C}_{17} \mathrm{H}_{14} \mathrm{O}_{7}, \mathrm{C}_{16} \mathrm{H}_{14} \mathrm{O}_{6}$, and $\mathrm{C}_{16} \mathrm{H}_{12} \mathrm{O}_{7}$, using ultra-performance liquid chromatography-quadrupole time-of-flight mass spectrometry (UPLC-Q-TOF MS). Similar studies were conducted by Patras et al. [17] who used the collimated 200-360 nm beam of a $1000 \mathrm{~W}$ medium-pressure UV lamp to irradiate water solutions with different aflatoxin concentrations. Irradiation doses of $4.88 \mathrm{~J} / \mathrm{cm}^{2}$ (meaning a 40 min treatment) were shown to reduce the aflatoxin concentrations as follows: $67 \%$ for aflatoxin $\mathrm{G}_{1}, 30 \%$ for aflatoxin $B_{2}$, and $98 \%$ for aflatoxin $B_{1}$. It was hypothesized that the aflatoxin degradation occurs through photolysis due to the $\mathrm{OH}$ radicals created by the ultraviolet (UV) radiation in the liquid media. The HepG2 in vitro cell culture model was used to assess the UV-irradiated aflatoxin's toxicity. It was demonstrated that increasing the UV dosage decreased the cytotoxicity caused by aflatoxins in the cells.

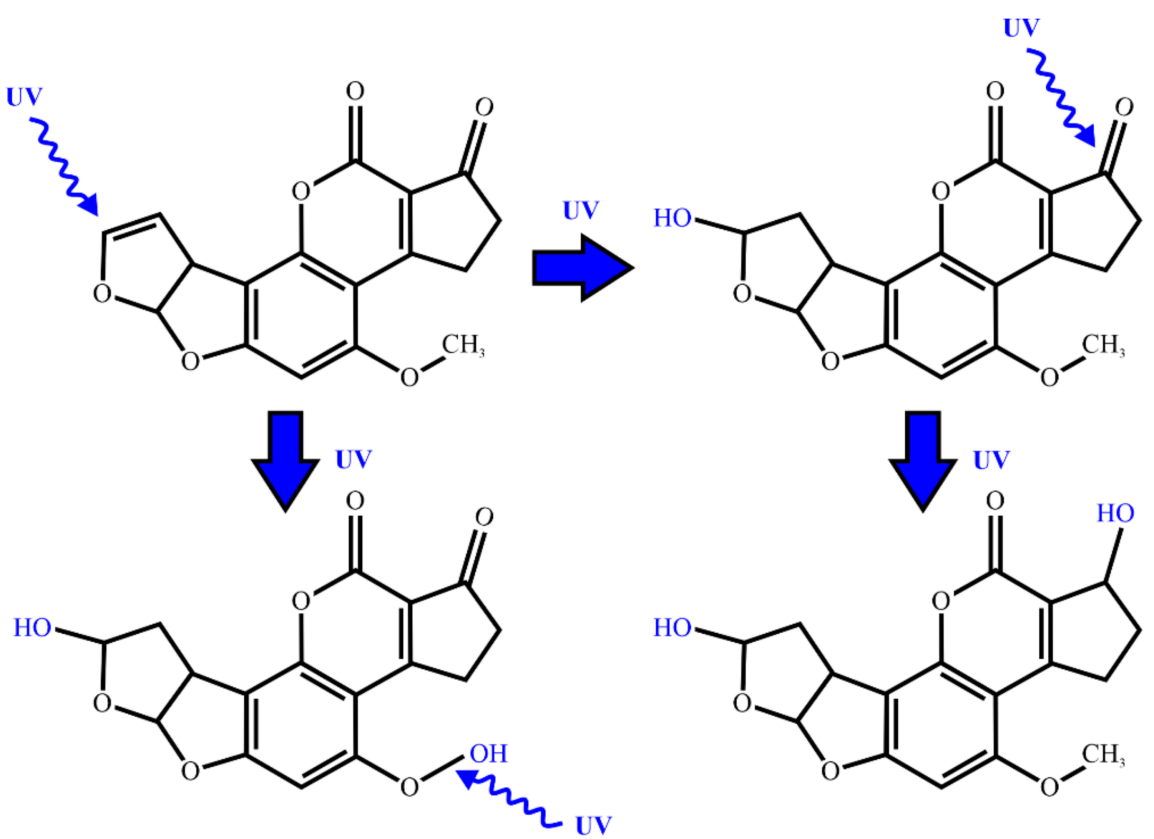

Figure 2. Mechanism of reaction with UV light; aflatoxin $\mathrm{AFB}_{1}$ reacts with photons of UV light in water (aqueous medium): 2 different degradation products are formed. Adapted from [16].

Atalla et al. [18] investigated the effect of UV (254 nm and $362 \mathrm{~nm})$ and fluorescent light (fluorescent tube $30 \mathrm{~W}$ ) on the mycotoxin production of different fungi grown on wheat grains. The wheat grains were artificially inoculated and treated at a distance of $5 \mathrm{~cm}$ and $25 \mathrm{~cm}$ from the UV and fluorescent lamps. After light treatment, the grains were stored for three weeks under different relative humidities: $50 \%, 74 \%$, and $80 \%$ at room temperature. It was found that a 30-60 min treatment completely halted the aflatoxin production of A. parasiticus. Shanakhat et al. [19] showed that UV irradiation of $15 \mathrm{~min}$ of aflatoxin-contaminated semolina could lead to the complete degradation of $\mathrm{AFB}_{1}$. A germicidal UV lamp with $30 \mathrm{~W}$ power providing UV-C radiation at $254 \mathrm{~nm}$ was used as a light source, and $100 \mathrm{~g}$ of the semolina layer of $1 \mathrm{~cm}$ thickness was exposed to the UV light at a distance of $15 \mathrm{~cm}$. The initial $\mathrm{AFB}_{1}$ concentration was $1.2 \mu \mathrm{g} / \mathrm{kg}$. 
The reduction in Aspergillus spp. counts and aflatoxin production by a $254 \mathrm{~nm}$ UV-C treatment was investigated on artificially inoculated hazelnuts by Basaran et al. [20]. With a $6 \mathrm{~h}$ ( $2 \mathrm{~h}$ periods repeated 3 times) UV-C $\left(9.99 \mathrm{~J} / \mathrm{cm}^{2}\right)$ treatment, a 2-log reduction in Aspergillus spp. counts and a $25 \%$ reduction in aflatoxins $\mathrm{B}_{1}$ and $\mathrm{G}_{1}$ were obtained. No changes in the macromolecular components of the hazelnuts due to the UV-C treatment were detected. Decontamination of infected nuts was also investigated by Jubeen et al. [21]. The moisture content of randomly selected nuts (ground and tree) was artificially increased to facilitate mold growth during 12 weeks of storage at $25-30{ }^{\circ} \mathrm{C}$. The fungal spores detected on the seeds immediately after selection belonged to Aspergillus flavus, Aspergillus parasiticus, and Penicillium. Inside transparent $1 \mathrm{~cm}$ thick polythene pouches, 200-250 g nuts were packed and then placed at a distance of $25 \mathrm{~cm}$ from a $265 \mathrm{~nm}$ UV source of $108 \mathrm{~J} / \mathrm{m}^{2}$. Treatments were performed for up to $45 \mathrm{~min}$ at room temperature. The fungicidal activity of UV-C radiation was found to be more pronounced in the nuts treated at the higher $16 \%$ moisture level, with levels of efficiency in the following order: walnut $>$ almond $=$ pistachio $>$ peanuts. A 45 min treatment resulted in $87 \%$ and $96 \%$ degradation of $\mathrm{AFB}_{1}$, depending on the moisture level, with the maximum reduction seen for almond and pistachio. The highest initial $\mathrm{AFB}_{1}$ level of $158.68 \mu \mathrm{g} / \mathrm{kg}$ was found in the peanuts, with a $16 \%$ moisture level, which also could be reduced by $96 \%$ with a 45 min treatment.

Another decontamination technique, supposedly based on UV radiation, is the pulsed light technique, which, compared to UV-lamps, has the advantages of a broad UV spectrum, a short duration, but high peak power. Moreau et al. [22] evaluated the effectiveness of pulsed light technology for degrading mycotoxins in a water solution. The treatment chamber was equipped with four orthogonally positioned xenon lamps (radiating in the 180-1100 nm wavelength range), which generated a light flux of $1 \mathrm{~J} / \mathrm{cm}^{2}$ during a single $300 \mu$ flash. Furthermore, $2 \mathrm{~mL}$ of mycotoxins (in the case of $\mathrm{AFB}_{1}$ of $5 \mu \mathrm{g} / \mathrm{mL}$ concentration) was exposed to one to eight flashes of pulsed light. It was found that eight flashes destroyed $84 \%, 72 \%, 92 \%$, and $98 \%$ of the zearalenone, deoxynivalenol, aflatoxin $\mathrm{B}_{1}$, and ochratoxin in the solution. By evaluating the genotoxicity of the mycotoxins, it was shown that the treatment of zearalenone and deoxynivalenol by single or multiple flashes of pulsed light marginally reduced their toxicity. In contrast, in the case of $\mathrm{AFB}_{1}$, pulsed light could completely eliminate its mutagenic potential. Similar studies with a similar xenon lamp were conducted by Wang et al. [23], investigating the effect of pulsed light on the degradation of $\mathrm{AFB}_{1}$ and $\mathrm{AFB}_{2}$ in rice bran and rough rice. Rough rice was inoculated with Aspergillus flavus and allowed to grow for 14 days to produce $\mathrm{AFB}_{1}$ and $\mathrm{AFB}_{2}$. Fifty grams of inoculated rough rice was spread uniformly in a single layer and treated for $20 \mathrm{~s}$ to $80 \mathrm{~s}$ in $20 \mathrm{~s}$ periods with $0.52 \mathrm{~J} / \mathrm{cm}^{2}$ pulses at room temperature. In the case of rice bran, a $3 \mathrm{~g}$ sample was spread uniformly with a thickness of $1 \mathrm{~mm}$ and treated in $5 \mathrm{~s}$ periods for up to $15 \mathrm{~s}$. It was found that the $80 \mathrm{~s}$ treatment of the contaminated rough rice could reduce the $A F B_{1}$ and $A F B_{2}$ levels by $75.0 \%$ and $39.2 \%$, respectively, while the $15 \mathrm{~s}$ treatment of the rice bran reduced the levels by $90.3 \%$ and $86.7 \%$, respectively. The genotoxicity tests showed that after treatment, the $\mathrm{AFB}_{1}, \mathrm{AFB}_{2}$, and their residual by-products had no mutagenic activity, while the toxicity of the two aflatoxins was significantly reduced.

\subsection{Ammoniation}

One method for aflatoxin deactivation in maize that is approved in several countries is ammoniation. The ammoniation process uses either ammonium hydroxide or gaseous ammonia. It can be utilized in two ways: a high-pressure and high-temperature (HP/HT) process or an atmospheric pressure and ambient temperature process (AP/AT). The HP/HT process involves treating the contaminated product with anhydrous ammonia and water in a contained vessel, with the amount of ammonia being $0.5-2 \%$, the moisture $12-16 \%$, the pressure 2.4-3.8 bar, the treatment time $20-60 \mathrm{~min}$, and the temperature $80-120{ }^{\circ} \mathrm{C}$. The AP/AT process also uses anhydrous ammonia and water sprayed on the seed as it is packed into a plastic silage-type bag. As the temperature and pressure are much lower, the 
processes can take 12-42 days. Park et al. [24] reviewed the reduction in aflatoxin hazards by ammoniation. The chemical effect of ammonia on aflatoxin inactivation is reported to start upon the opening of the lactone ring of $\mathrm{AFB}_{1}$ and is followed by ammonium salt forming from the resulting hydroxy acid (Figure 3). The reversion of reaction products back to the parent $\mathrm{AFB}_{1}$ was observed under acidic conditions when the exposure time and process conditions were insufficient [25].
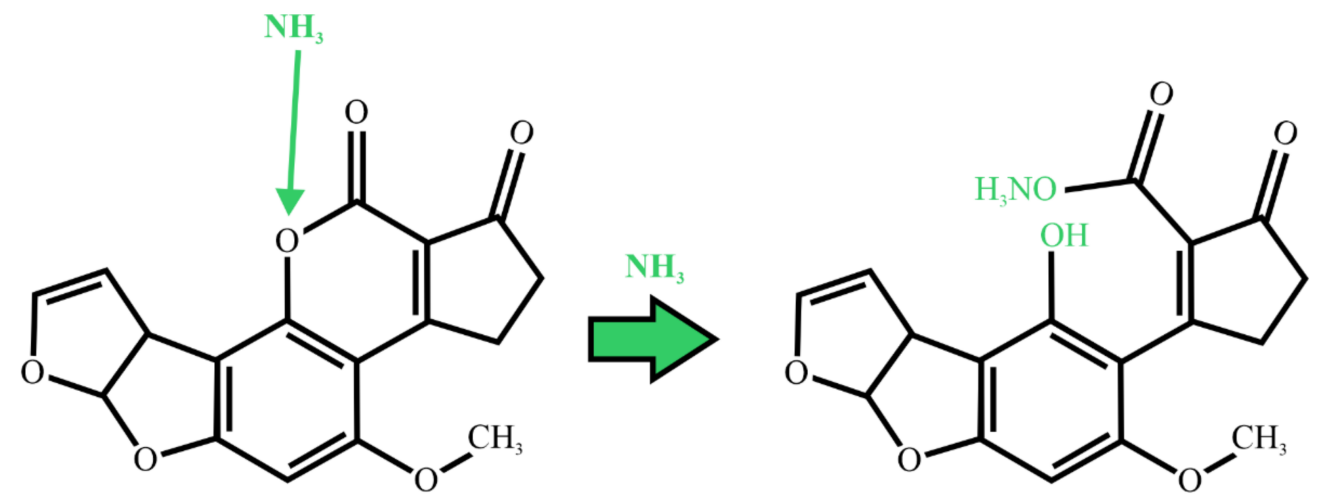

Figure 3. Mechanism of reaction of ammoniation of $\mathrm{AFB}_{1}$. Adapted from Stanley et al. [26].

The aflatoxin/ammonia reaction has several products, their relative amounts being dependent on the temperature and pressure conditions used and whether ammonium hydroxide or ammonia gas is the ammonia source [25-28]. These products have been found to hold a relative mutagenic/toxic potential (the covalent bonding to the DNA) that is 20- to 3000-fold less than the parent aflatoxin [25]. The efficiency and the irreversibility of the ammoniation process on naturally contaminated corn were demonstrated by Weng et al. [29], who treated $50 \mathrm{~g}$ of naturally contaminated, ground yellow corn containing $7500 \mathrm{ng} / \mathrm{g}$ of $\mathrm{AFB}_{1}$ for $60 \mathrm{~min}$ in several different conditions with respect to the ammonia concentration, moisture level (12\% and $16 \%$ ) of the corn, temperature, and applied pressure. The treatment with $2 \%$ gaseous $\mathrm{NH}_{3}$ at $40-45{ }^{\circ} \mathrm{C}$ and 3.8 bar reduced the $\mathrm{AFB}_{1}$ level in samples containing $12 \%$ moisture by $15 \%$ (from $67.7 \%$ to $52.7 \%$ ), while in the samples containing $16 \%$ moisture the reduction changed from $93.1 \%$ to $79.4 \%$, i.e., by $14 \%$. The treatment with aqueous $\mathrm{NH}_{4} \mathrm{OH}$ alone at $121^{\circ} \mathrm{C}$ and 1.2 bar, or followed by gaseous $\mathrm{NH}_{3}$ treatment, reduced the $\mathrm{AFB}_{1}$ content by more than $99 \%$. Reversibility was found to be less than $0.05 \%$. Corn was also treated in an industrial-scale mobile ammonia treatment plant capable of processing 50 metric tons of whole kernel corn per hour. Over 30,000 metric tons of corn containing aflatoxin levels ranging from 100 to $500 \mu \mathrm{g} / \mathrm{kg}$ was successfully treated to reduce the aflatoxin levels to below $20 \mu \mathrm{g} / \mathrm{kg}$.

Gomaa et al. [30] treated artificially infected corn with a final $4000 \mu \mathrm{g} / \mathrm{kg}$ aflatoxin contamination with AP/AT or HP/HT (high pressure of 2 bar and temperature of $121^{\circ} \mathrm{C}$ ) methods. The moisture content of the corn was adjusted to an $18 \%$ wet basis and sprayed to provide levels of $0.25 \%$ to $2 \%$ ammonia on a dry-matter basis. Polyethylene bags were filled with $1 \mathrm{~kg}$ of contaminated corn and treated under AP/AT or HP/HT conditions for $24 \mathrm{~h}$. It was found that the efficiency of destroying the aflatoxins increased with a higher ammonia concentration. At atmospheric pressure (AP/AT), 90\% total aflatoxin destruction was obtained with $2.0 \%$ ammonia, while at high pressure $(\mathrm{HP} / \mathrm{HT})$ the destruction exceeded 99\%. With the AP/AT method, the highest $99 \%$ destruction was reported by Norred et al. [31] on $1000 \mu \mathrm{g} / \mathrm{kg}$ of naturally aflatoxin-contaminated corn.

\subsection{Ozonation}

Another technique still attracting considerable research attention is the use of ozone (both aqueous and gaseous ozone) to reduce fungal and mycotoxin contamination. The different ozone-generation methods, such as water electrolysis or electrical gas discharge, by allowing the ozone production on-site from ambient air, offered a significant advantage 
over other techniques that require costly production, storage, and transportation. Ozone decomposes into atomic and molecular oxygen, meaning that in this process there are no residues of toxic chemicals, no danger of chemical-mixing hazards, and no need to specially treat the exhaust. A suggested initial stage in the transformation of $\mathrm{AFB}_{1}$ upon ozonation is presented in Figure 4.

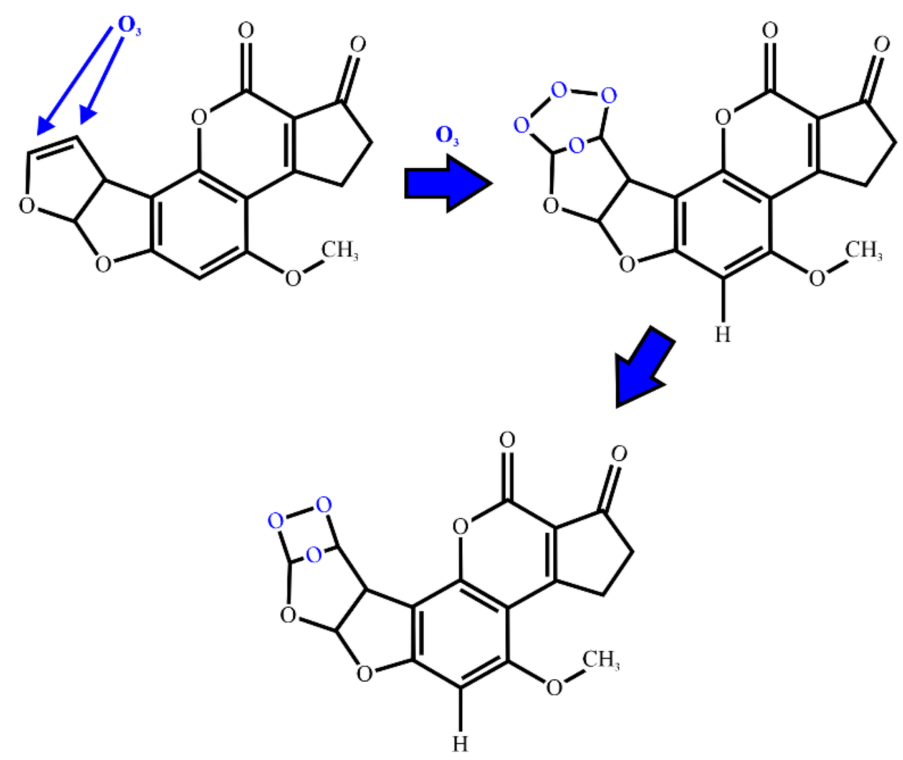

Figure 4. The reaction mechanism of $\mathrm{AFB}_{1}$ with ozone, $\mathrm{O}_{3}$. Degradation leads to aflatoxin molozonide and further, spontaneously, to aflatoxin ozonide. Adapted from [6].

While the ammoniation opens the lactone ring in the coumarin, ozone attacks the C8C9 double bond on the terminal furan responsible for the mutagenicity and carcinogenicity of the aflatoxins [8], which causes them to break down into organic acids, aldehydes, ketones, and carbon dioxide [32,33]. The effect of ozone on naturally contaminated corn with $\mathrm{AFB}_{1}$ was tested by McKenzie et al. [32]. Corn contaminated with $1220 \mu \mathrm{g} / \mathrm{kg} \mathrm{AFB}_{1}$ was treated for $92 \mathrm{~h}$ with $14.0 \mathrm{wt} \% \mathrm{O}_{3}$ at a flow rate of $200 \mathrm{mg} / \mathrm{min}$ in $30 \mathrm{~kg}$ batches, which led to an $\mathrm{AFB}_{1}$ reduction of over 95\%. The corn's toxicity was tested on turkeys by feeding them with clean (control), treated control, untreated, and treated $\mathrm{AFB}_{1}$ corn, respectively. Compared with the controls, the turkeys fed the $\mathrm{AFB}_{1}$ corn gained less body and relative liver weight, whereas the turkeys fed the ozone-treated control or ozone-treated $\mathrm{AFB}_{1}$ corn did not differ from the controls. Furthermore, alterations in the majority of the relative organ weights, liver discoloration, serum enzyme activity, hematological parameters, and blood chemistry caused by $\mathrm{AFB}_{1}$ were eliminated by the ozone treatment [32].

Luo et al. [34] examined the effect of ozone treatment on degrading $\mathrm{AFB}_{1}$ in artificially infected maize. They evaluated the toxicity of the degradation products using the human hepatocellular carcinoma cell line (HepG2) as model cells. Corns of different moisture content were treated in $10 \mathrm{~g}$ batches in a $1 \mathrm{~L}$ glass reactor in flowing gas with ozone concentrations ranging from $40-90 \mathrm{mg} / \mathrm{L}$ for up to $40 \mathrm{~min}$ at $25{ }^{\circ} \mathrm{C}$ and $75 \%$ relative humidity. The results showed that the degradation was more efficient in the lower $13.47 \%$ of the moisture content of the corn, and the $20 \mathrm{~min}$ and $40 \mathrm{~min}$ treatment with $90 \mathrm{mg} / \mathrm{L}$ ozone led to decreases of $83 \mu \mathrm{g} / \mathrm{kg} \mathrm{AFB}_{1}$ to $18.12 \mu \mathrm{g} / \mathrm{kg}$ and $9.9 \mu \mathrm{g} / \mathrm{kg}$, respectively. The toxicity test showed the $\mathrm{AFB}_{1}$-contaminated corn extract had high cell toxicity, while the ozonetreated infected corn had no significant effect, similar to the $\mathrm{AFB}_{1}$-free culture solution.

Prudente et al. [35] demonstrated the effect of ozonation on naturally contaminated corn. Contaminated and non-contaminated corn seeds were treated in $113 \mathrm{~L}$ containers with 10 to $12 \mathrm{wt} \%$ ozone, flowing at a flow rate of $2 \mathrm{~L} / \mathrm{min}$, for $96 \mathrm{~h}$ at 12 to $15 \mathrm{~h}$ intervals, with mixing occurring every $30 \mathrm{~h}$. This produced a $92 \%$ reduction in $\mathrm{AFB}_{1}$, with the $\mathrm{AFB}_{1}$ level decreasing from $586.8 \mu \mathrm{g} / \mathrm{kg}$ to $47.7 \mu \mathrm{g} / \mathrm{kg}$, while no reversion of inactivated aflatoxin to 
the parent compound was observed. The $\mathrm{AFB}_{1}$ could be further reduced to about $29 \mu \mathrm{g} / \mathrm{kg}$ through exposure to an acidic environment in the ozone-treated corn. It had previously been shown that the acid treatment led to hydration of $\mathrm{AFB}_{1}$ at the 8,9-olefinic bond of the terminal furan ring to form aflatoxin $B_{2 a}$, whose toxicity was less than $1 / 200$ that of $\mathrm{AFB}_{1}$ [14]. It was also found that the ozonation of clean corn had no significant effect on the saturated and unsaturated fatty acids. In contrast, in contaminated corn, the percentage of unsaturated fatty acid was significantly reduced from $82.0 \%$ to $79.1 \%$, whereas the saturated fatty acid composition rose from $18.0 \%$ to $20.9 \%$. While evaluating the mutagenicity of corn extract, it was found that the ozonation procedure reduced the mutagenic potential of the $\mathrm{AFB}_{1}$-contaminated corn, suggesting that the ozonation process may have caused the formation of fat-soluble reaction products that hold relatively low mutagenic potential. It was also hypothesized that the ozonation decontamination process might have produced oxidation products such as oxidized linoleic acid, malonaldehyde, and acrolein that have been shown to be mutagenic in the Salmonella mutagenicity assay [35].

Using infected peanut kernel, Proctor et al. [36] showed that aflatoxins $B_{1}$ and $G_{1}$ are more sensitive to ozone and heat treatment than $B_{2}$ and $G_{2}$, which is significant given that aflatoxins $B_{1}$ and $G_{1}$ are the most potent toxins known. However, the highest level of degradation of $\mathrm{AFB}_{1}(77 \%)$ was obtained when the ozone treatment was performed at an elevated temperature of $75^{\circ} \mathrm{C}$.

The inhibitory effect of ozone on the growth of Aspergillus flavus and the $\mathrm{AFB}_{1}$ production were investigated by Ta et al. [37] in vitro, using culture media. They showed that $40 \mathrm{ppm}$ ozonation inhibited the mycelial growth of fungi by $65 \%$ and $95 \%$ for the $5 \mathrm{~min}$ and $20 \mathrm{~min}$ treatments, respectively. Moreover, the $\mathrm{AFB}_{1}$ production also decreased, while in the untreated sample the $\mathrm{AFB}_{1}$ concentration was $185 \mu \mathrm{g} / 100 \mathrm{~mL}$; in the $20 \mathrm{~min}$ treated sample, it was only $42 \mu \mathrm{g} / 100 \mathrm{~mL}$. These results infer that, with ozonation, the growth of fungi can be stopped (or they can even be killed) prior to the grains being stored, inhibiting the production of $\mathrm{AFB}_{1}$.

The effect of ozone on seed germination, which is an important factor if crops are meant to be used as seeds, was investigated for barley by Allen et al. [38] using different ozone doses. It was established that ozone doses of less than $0.98 \mathrm{mg} /(\mathrm{g}$ barley) $/ \mathrm{min}$ showed no effect on barley germination even after $45 \mathrm{~min}$ of ozonation. When using an ozone dose of $0.98 \mathrm{mg} /(\mathrm{g}$ barley) $/ \mathrm{min}$, at ozonation times longer than $10 \mathrm{~min}$, the germination started to decrease and saw a reduction of $30 \%$ after a 45 min treatment. A similar test was conducted on wheat by Savi et al. [39], showing that with a $120 \mathrm{~min}$ exposure to $60 \mu \mathrm{mol} / \mathrm{mol} \mathrm{O}$ wheat germination was not affected, while a 180 min exposure reduced the germination capacity by $12.5 \%$. In addition, at both treatment times, no modifications in the length of the coleoptile or the seminal root of the germinated wheat seeds were observed. They also tested the penetration efficiency of ozone into the kernel. Deoxynivalenol (DON) injected by syringe into the grain endosperm was found to have been reduced to the limit of detection after $180 \mathrm{~min}$ of treatment.

Kells et al. [40] intended to optimize the ozone flow in a 12.7-tonne capacity, $3 \mathrm{~m}$ diameter galvanized steel grain bin where ozone was forced downward through the grain to exit the plenum. They treated 8.9 metric tons of maize with $50 \mathrm{ppm}$ ozone for $3 \mathrm{~d}$, which led to a $92-100 \%$ mortality of several insects and a $63 \%$ reduction in fungus contamination of the kernel surface. Two distinct phases were identified in the penetration and distribution of ozone in the system. The first phase was characterized by the ozone's rapid degradation and slow movement through the grain until the active sites became saturated, which depended on the gas flow velocity. In contrast, in the second phase, the ozone flowed freely through the grain with little degradation. For efficient fumigation, the second phase should be achieved while the time for the first phase should be minimized. The generator used in the study produced $50 \mathrm{ppm}$ of ozone at an apparent velocity of $0.0030-0.0036 \mathrm{~m} / \mathrm{s}$. Ozone was detected within $0.5 \mathrm{~d}$ at a depth of $0.3 \mathrm{~m}$ in the center, $1 \mathrm{~d}$ at $0.9 \mathrm{~m}$ in the center, $12 \mathrm{~d}$ at $1.5 \mathrm{~m}$ in the center, $18 \mathrm{~d}$ at $1.8 \mathrm{~m}$ in the center, $8 \mathrm{~d}$ at $1.5 \mathrm{~m}$ from the southern wall, and after $13 \mathrm{~d}$ at $1.8 \mathrm{~m}$ from the southern wall of the bin. The ozone levels stabilized at $20 \mathrm{~d}$; 
however, the first phase was not completed. In the case of a much smaller, $0.57 \mathrm{~m}$ diameter laboratory reactor, an optimum gas velocity of $0.03 \mathrm{~m} / \mathrm{s}$ was determined, which allowed the deep penetration of ozone into the grain mass, namely $85 \%$ of the ozone penetrated $2.7 \mathrm{~m}$ into the column of the grain in $0.8 \mathrm{~d}$ during the first phase.

It was demonstrated that ozonation could efficiently reduce the grain's surface contamination with microorganisms, insects, and mycotoxins; yet, long treatment times are needed, which in the case of industrial-scale storage bins can take weeks. A disadvantage of this long treatment is that the high ozone concentration required for decontamination can also induce noticeable damage to the equipment through corrosion. On the other hand, in kernels naturally contaminated with mycotoxins, the achieved decontamination does not reach the safety level due to the ozone's low penetration efficiency into the kernel. An alternative to ozonation and ammoniation could be gas discharge plasmas, rich in reactive oxygen and nitrogen species, UV radiation and energetic particles, which provide the synergy of the oxidative species and UV radiation and may also enhance the penetration of oxidative species.

\section{Characteristics of Aflatoxins and Detoxification Methods}

\subsection{Relevance of Non-Thermal Gas Discharge Plasmas for Agriculture}

Gas discharge plasmas are weakly ionized gases generated from neutral gases by energy input. The energy is preferentially transferred to the electrons, due to which the neutral species' temperature, and thus the gas temperature, remains low, close to room temperature, while the electrons gain high energies that make them able to ionize, excite, and dissociate the background gas molecules. In plasmas generated from nitrogen and oxygencontaining gas mixtures with a certain humidity, reactive oxygen and nitrogen atoms, reactive metastable oxygen molecules, ozone, $\mathrm{OH}$ and $\mathrm{NO}$ radicals, and UV-radiating excited species can be created, which opens up the field of biological applications of gas discharges.

In general, low-pressure discharges can be generated in large volumes. The most common discharge systems relevant to large-scale applications are the direct current and capacitively coupled radio-frequency discharges, which are generated between two electrodes [41-43], electrodeless inductively coupled radio frequency discharges [43-45], and surface-wave microwave discharges [46]. The active species generated in smaller volume discharges can also be transported by gas flow into larger volume reactors called plasma afterglows $[44,45]$. In low-pressure systems, the samples should be placed in a vacuum, which may prove to be a limiting factor for some biological samples. On the other hand, at atmospheric pressure, where no vacuum system is needed, the size of the plasma is limited to a few millimeters in the vicinity of the discharge electrode due to the very short mean free path length of energetic electrons [47]. The atmospheric pressure systems of relevance to industrial applications are dielectric barrier discharges (DBD) formed in the narrow gaps between closely spaced electrodes, at least one of which is covered by a dielectric [48], the surface dielectric barrier discharges (SDBD) [49,50], and plasma jets, where the applied zone is the afterglow similar to the low-pressure case [51].

Research on the applicability of discharge plasmas to biological systems has boomed in the last two decades. At the beginning, studies focused on medical tools and wound sterilization (bacteria, virus, and protein inactivation), suggesting different low-pressure $[45,49,52]$ and non-thermal high-pressure discharge systems $[53,54]$. The success of non-thermal discharge plasmas in sterilization led to broader applications, such as in agriculture and food processing $[52,55]$. In the field of agriculture, the research first focused on improving seed germination and plant growth and cleaning from pathogens using gas phase plasma species, such as $\mathrm{OH}, \mathrm{O}_{3}$ and $\mathrm{NO}$ molecules, O-atoms, and $\mathrm{UV}$ radiation [56,57]. In the case of seed germination, it is generally accepted that ROS and NO are crucial for breaking the dormancy of the seeds $[58,59]$.

Low-pressure systems were used to test the effect of plasma species on seed germination and to reduce seed-surface contamination. Barley and corn seeds were treated with 
a direct current (DC) low-pressure discharge in the residual atmosphere at $15 \mathrm{~Pa}$. It was found that the fungal load could be significantly reduced with a 20 min treatment, while the germination rate of barley decreased by $12 \%$ and that of corn by $5 \%$ [60]. It was established that the efficiency of the treatment depends on the type of seed, size, and surface properties. At a higher pressure of $150 \mathrm{~Pa}$, wheat seeds were treated with helium capacitively coupled radio-frequency discharge (CCP) with an electrode distance of $2 \mathrm{~cm}$ for $15 \mathrm{~s}$. This treatment was found to increase the germination and growth rate and the production yield [61]. We note that here the presence of reactive oxygen and nitrogen species is minimal. On the contrary, when using the afterglow of an air microwave discharge (rich in reactive species) at the same pressure $(140 \mathrm{~Pa}, 500 \mathrm{~W})$, it was established that treatment times of $180-2400 \mathrm{~s}$ led to decreased wheat germination and had no significant effect on the oat seeds [62].

Szóke et al. [63], using the flowing afterglow of a low-pressure $\mathrm{Ar} / \mathrm{N}_{2} / \mathrm{O}_{2}$ surfacewave microwave discharge (abundant in $\mathrm{O}$ and/or $\mathrm{N}$ atoms, $\mathrm{O}_{2}(\mathrm{a})$ and $\mathrm{NO}$ molecules, and UV radiation), studied the effect of the ROS and reactive nitrogen species (RNS) on barley and corn seed germination, and their surface disinfection from two types of Fusarium: graminearum and verticillioides. It was shown that the germination and vigor of the noninfected seeds were not significantly affected when barley was treated for $120 \mathrm{~s}$ at $200 \mathrm{~Pa}$ and corn for $240 \mathrm{~s}$ at $400 \mathrm{~Pa}$. On the other hand, the seeds could be decontaminated from the germination inhibitors Fusarium graminearum and Fusarium verticillioides, namely when barley was treated for $3 \mathrm{~min}$ at $400 \mathrm{~Pa}$ in the afterglow of the mixture of $80 \% \mathrm{Ar}$ and $20 \% \mathrm{O}_{2}$ discharge and corn for $4 \mathrm{~min}$ at $800 \mathrm{~Pa}$ in the mixture of $80 \% \mathrm{Ar}$ and $20 \% \mathrm{O}_{2}$, followed by a 2 min treatment in the $\mathrm{N}_{2}-2 \% \mathrm{O}_{2}$ afterglow. These treatments also increased the germination of the infected seeds from $35 \%$ and $50 \%$, respectively, to above $80 \%$. It was also found that high NO content mixtures and the heating of the seed surface by the recombination of $\mathrm{O}$ and $\mathrm{N}$-atoms inhibited barley germination. Zahoranova et al. [64] used an SDBD in ambient air in atmospheric pressure conditions. They showed that a $90 \mathrm{~s}$ treatment of artificially infected wheat seeds could completely inactivate Fusarium nivale and Fusarium culmorum, while for Aspergillus flavus $240 \mathrm{~s}$ was needed. However, the results showed that the seeds did not germinate after treatment. These results reveal that fine-tuning of the plasma species is needed to decontaminate seeds without inhibiting their germination.

\subsection{Degradation of Mycotoxins by Discharge Plasmas}

In the last two decades, comprehensive work has been undertaken to study the interaction of plasma species with bacteria, bacteria spores, and prions (infectious proteins). The microbial inactivation ability of the discharge plasmas was generally attributed to the oxidizing species, such as $\mathrm{O}$-atoms, singlet metastable $\mathrm{O}_{2}(\mathrm{a}), \mathrm{O}_{3}, \mathrm{OH}$, the energetic ions, and UV radiation. The $\mathrm{O}$-atoms can etch the organic material, thereby contributing to the volatilization of the proteins and the protective cell wall of bacteria and spores [65]. A similar role can also be attributed to the other oxygen species. Furthermore, energetic ions in the plasma environment can enhance the etching efficiency as a synergetic effect of the physical sputtering by ions and chemical etching by oxygen species [66]. Once the integrity of the cell wall is damaged, the UV radiation can penetrate the cell, reach the DNA, and induce strand breaks, thus stopping the cells from replicating [67]. It was also suggested that electrostatic forces could cause rupture of the cell membrane and, subsequently, cell death due to the accumulation of charged species on the outer cell membrane [53]. Based on these studies, the investigations were extended to mycotoxins.

There are several methods for detecting and quantifying aflatoxins in foods, including thin-layer chromatography (TLC), high-performance liquid chromatography (HPLC), mass spectroscopy (MS), enzyme-linked immune-sorbent assay (ELISA), and electrochemical immunosensor. Each of these methods has its advantages and limitations in aflatoxins analysis [68]. The degradation of different mycotoxins by gas discharge plasmas was studied by Park et al. using an argon atmospheric pressure microwave discharge [69]. The discharge was generated at the end of a quartz nozzle using a gas flow rate of $100 \mathrm{~L} / \mathrm{min}$. The intensity of UV light radiated by the plasma was detected to be in the range of 
$75-102 \mathrm{~mW} / \mathrm{cm}^{2}$ at a wavelength of $254 \mathrm{~nm}$. For the degradation test, these mycotoxins were dissolved in chloroform, and afterwards, the suspensions were inoculated on glass slides and allowed to dry at room temperature. The inoculated glass slides were placed in front of a nozzle and treated for 1,3,5, and $10 \mathrm{~s}$, respectively. After plasma treatment, the samples were recovered from the glass slides by dissolution. These extracts were used to determine the mycotoxin concentration and cytotoxicity of the reaction products on the cell cultures. It was found that the concentrations of aflatoxin $B_{1}$, deoxynivalenol, and nivalenol (NIV) had fallen below the detection limit after the $5 \mathrm{~s}$ plasma treatment. It was concluded that the degradation and the removal of mycotoxins were due to the UV irradiation and the etching by the plasma species. It was also shown that while the standard $\mathrm{AFB}_{1}, \mathrm{DON}$, and NIV resulted in a significant dose-dependent decrease in the viability of mouse macrophage cells, implying their high cytotoxicity to mammalian cells even at micromolar concentrations, the plasma treatment reduced the viability loss of macrophages; the mycotoxin-induced cytotoxicity was completely prevented after $5 \mathrm{~s}$ of incubation.

The degradation of $\mathrm{AFB}_{1}$ by a low-pressure discharge and the resulting products were studied by Wang et al. [70]. A CCP discharge was generated in a stainless-steel cylindrical chamber of $200 \mathrm{~mm}$ diameter and $300 \mathrm{~mm}$ height in residual air at $15 \mathrm{~Pa}$. The chamber's temperature was maintained at about $40{ }^{\circ} \mathrm{C}$. The $\mathrm{AFB}_{1}$ was exposed to the plasma in powder form after the solutions were dried by nitrogen purging. Various amounts of $\mathrm{AFB}_{1}(2,10$, and $50 \mu \mathrm{g})$ were treated for different lengths of time under several input power conditions $(100,200$, and $300 \mathrm{~W})$. Following the plasma treatments, the samples were dissolved in acetonitrile, and their $\mathrm{AFB}_{1}$ content was determined with the HPLC method. It was found that independently of the initial $\mathrm{AFB}_{1}$ concentration, the $10 \mathrm{~min}$ treatment with the $300 \mathrm{~W}$ discharge led to a degradation rate of up to $88.3 \%$. The degradation products were identified with ultra-high performance liquid chromatography with quadrupole time-of-flight mass spectrometry (UPLC-Q-TOF MS). Five major compounds were identified $\left(\mathrm{C}_{12} \mathrm{H}_{14} \mathrm{O}_{4}, \mathrm{C}_{16} \mathrm{H}_{17} \mathrm{O}_{9}, \mathrm{C}_{16} \mathrm{H}_{17} \mathrm{O}_{7}, \mathrm{C}_{17} \mathrm{H}_{17} \mathrm{O}_{9}\right.$, and $\left.\mathrm{C}_{16} \mathrm{H}_{17} \mathrm{O}_{8}\right)$, which lost their double bonds in the terminal furan ring, due to which they theoretically had reduced toxicity compared with $\mathrm{AFB}_{1}$, according to the structure-activity relationship; albeit, no cell tests were conducted.

Siciliano et al. studied the degradation of four aflatoxins (aflatoxins $B_{1}, G_{1}, B_{2}$, and $\mathrm{G}_{2}$ ) in standard solutions using an atmospheric pressure DBD [71], which had a coaxial electrode system and operated at about 7 bar in a crosswise gas flow mode. The gas flow rate used was about $120 \mathrm{~L} / \mathrm{min}$. The plasma was generated in pure $\mathrm{N}_{2}$ and $\mathrm{N}_{2} / \mathrm{O}_{2}$ gas mixtures with a $100-150 \mathrm{kHz}$ voltage. Different powers in the $400-1150 \mathrm{~W}$ range and treatment times from 1 to $12 \mathrm{~min}$ were tested when the samples were positioned at $50 \mathrm{~mm}$ from the plasma source. The treatments were performed in an isolated chamber to maintain the sample in a controlled atmosphere and temperature. The mixtures of the aflatoxins' standards were prepared by diluting the original standards at the final concentration of $10 \mathrm{ng} / \mathrm{mL}$. As the experiments were conducted with aflatoxins in aqueous solutions, the reactive species were those created in the liquid phase by the plasma-liquid interaction, such as $\mathrm{OH}, \mathrm{O}_{2}(\mathrm{a}), \mathrm{H}_{2} \mathrm{O}_{2}, \mathrm{O}_{3}, \mathrm{NO}_{2}{ }^{-}, \mathrm{NO}_{3}{ }^{-}$, and peroxynitrite [72]. The results showed that the greatest detoxification efficacy was obtained with nitrogen or $\mathrm{N} / 20.1 \% \mathrm{O}_{2}$ initial mixture discharges at $400 \mathrm{~W}$ for a 12 min treatment. When increasing the power to $1000 \mathrm{~W}$, the appropriate treatment time decreased to $2 \mathrm{~min}$. We should note that the nitrogen discharge favors the formation of nitrite, nitrate, and peroxynitrite in the aqueous solution [72]. These results indicate that plasma-activated water might hold relevance for seed decontamination.

\subsection{Decontamination of Artificially Infected Seeds by Discharge Plasmas}

Based on the results obtained using aqueous solutions of aflatoxins, Siciliano et al. [71] used the same DBD setup and procedure to treat $40 \mathrm{~g}$ of hazelnuts artificially contaminated with aflatoxins. Shell-less raw hazelnuts were sprayed with an aflatoxin solution containing four aflatoxins, obtaining contamination of $20 \mathrm{ng} / \mathrm{g}$ for each aflatoxin. The treatments were 
performed using pure nitrogen as the initial gas. Unlike the aqueous solution, none of the treatments resulted in total detoxification. However, there was a clear trend towards higher detoxification efficacy with increasing treatment time or power. One should note that although the two treatments look similar, the interacting active species are different as the aflatoxins deposited onto the seeds were treated in the gas phase and not in an aqueous environment. When applying atmospheric nitrogen DBD at a $50 \mathrm{~mm}$ distance, it is expected to have the $\mathrm{N}$-atoms, $\mathrm{N}_{2}$ metastables, and $\mathrm{NO}$ molecules as active species due to the oxygen impurities and UV radiation, which are not the most efficient species for degrading aflatoxins. Consequently, the highest detoxification of $\mathrm{AFB}_{1}$ and total aflatoxins on hazelnuts, around $70 \%$, was obtained at the highest $1150 \mathrm{~W}$ power with the longest (12 min) treatment time. It was also shown that during the most prolonged treatment at the highest power, the temperature increased to a maximum of $59^{\circ} \mathrm{C}$, which is expected not to affect the qualitative properties of hazelnuts. These treatments were considerably milder and less efficient than those of Park et al. with the argon atmospheric pressure microwave discharge [69], where the charged species also participated in the etching process. At the same time, the temperature and UV radiation were also higher.

A low-frequency plasma jet, similar to the microwave plasma jet used by Park et al., was tested by Dasan et al. [73] on artificially infected maize seeds inoculated with aflatoxinproducing Aspergillus flavus and Aspergillus parasiticus. After inoculation, the artificially contaminated seeds were incubated at $25-28{ }^{\circ} \mathrm{C}$ for $18-24 \mathrm{~h}$ to enable mold spores to adhere to the surface and to remove the extra moisture gained during fungal inoculation. The plasma source used was an atmospheric pressure plasma jet (Plasmatreat $\mathrm{GmbH}$, Steinhagen, Germany) equipped with a stainless-steel nozzle. The discharge was generated between the tip of a high-voltage needle electrode (powered with $5-10 \mathrm{kV}$ at $18-25 \mathrm{kHz}$ frequencies, to a maximum power of $655 \mathrm{~W}$ ) to the inner wall of the nozzle, using a $3000 \mathrm{~L} / \mathrm{h}$ gas flow rate, due to which the plasma expanded $20 \mathrm{~mm}$ outside of the nozzle. The plasma jet was connected to the bottom of the treatment reactors (fluidized bed reactors with diameters of 49 and $65 \mathrm{~mm}$ and lengths of 147 and $195 \mathrm{~mm}$, respectively), where the samples were repeatedly conveyed to the treatment zone by employing an aeration gas flow supplied from a compressor with a $900 \mathrm{~L} / \mathrm{min}$ air yield. As a consequence, the seeds in the reactor were in contact with the plasma afterglow. Forty grams of seeds was treated with dry and filtered air and nitrogen for 1-5 min. It was found that after $5 \mathrm{~min}$ of air plasma treatment, the initial fungal load concentration $(7 \mathrm{log}(\mathrm{cfu} / \mathrm{g}))$ had dropped by 5.48 and $5.20 \log (\mathrm{cfu} / \mathrm{g})$ for the Aspergillus flavus and Aspergillus parasiticus spores, respectively. At the same time, the native microbial flora of the maize grains, initially about $3 \log (\mathrm{cfu} / \mathrm{g})$, had decreased to an undetectable level after $3 \mathrm{~min}$ of plasma treatment. Compared to the nitrogen plasma, the air plasma was more efficient due to the appearance of reactive oxygen species, such as $\mathrm{O}$-atoms, ozone, and $\mathrm{OH}$, which directly impact the cells of microorganisms, especially on their outermost membranes made up of lipid bilayers. The plasma treatment's fungicidal effect was attributed to the destruction of the spore integrity. It was also shown that during the storage of the plasma-treated maize at $25^{\circ} \mathrm{C}$ for 30 days, the Aspergillus spp. spores' log reduction was maintained with no occurrence of re-growth.

In contrast to atmospheric pressure plasmas where, as illustrated by the works presented above, only a modest amount of seeds can be treated, low-pressure systems provide larger plasma volumes and allow larger amounts of seeds to be treated. Selcuk et al. [74] tested the inactivation of Aspergillus spp. and Penicillium spp. fungi artificially inoculated on seed surfaces by air and $\mathrm{SF}_{6}$ (which is less relevant for food and feedstuff treatment) plasmas. The plasma system used was an inductively coupled discharge (ICP) generated with $300 \mathrm{~W}$ input power at $66.6 \mathrm{~Pa}$ in a quartz tube of a $5 \mathrm{~mm}$ diameter and $40 \mathrm{~mm}$ length by applying a $1 \mathrm{kHz}$ sinusoidal $20 \mathrm{kV}$ voltage. In the center of the discharge tube, $8 \mathrm{~g}$ of seeds was placed and periodically rotated to ensure the surface of seeds had the same treatment. The studies were conducted on several seeds: wheat (Triticum durum), bean (Phaseolus vulgaris), chickpea (Cicer arietinum L.), soybean (Glycine max cv), barley (Hordeum 
vulgare L. cv.), oat (Avena sativa), rye (Secale cereale), lentil (Lens culinaris), and corn (Zea mays). The treatment was established to be the most efficient in the case of contaminated wheat. With $20 \mathrm{~min}$ of air plasma treatment, the initial fungus colony of $4.1 \times 10^{7} \mathrm{cfu} / \mathrm{g}$ decreased to less than $1 \times 10^{4} \mathrm{cfu} / \mathrm{g}$, which remained stable over time. Similar results were obtained for the $\mathrm{SF}_{6}$ plasma. However, with $\mathrm{SF}_{6}$, the first phase of the inactivation process occurred at a higher rate. In the case of corn, only a 1-log reduction in the fungal spore population was achieved. The results indicated a relationship with the effectiveness of the plasma being used. It was also found that the plasma treatment had no significant effect on the germination of wheat and bean seeds. The results also showed that the quality of wheat (wet gluten content, gluten index) and beans (water uptake and cooking parameters) were not or were only marginally affected by the plasma treatment. One should note that in this low-pressure system, the seeds were exposed not only to reactive neutral species but also to energetic charge species, which play a significant role in the etching process.

The efficiency of aflatoxin degradation was studied by Basaran et al. [75] in the case of nuts artificially contaminated with aflatoxin-producing Aspergillus parasiticus. It was found that the artificially contaminated hazelnuts (106 conidiospores/g) contained $950 \mathrm{ng} / \mathrm{g}$ of total aflatoxins $\left(B_{1}, B_{2}, G_{1}\right.$, and $\left.G_{2}\right)$ which, following a 20 min $\mathrm{SF}_{6}$ treatment, decreased to $751 \mathrm{ng} / \mathrm{g}$. Furthermore, although the air treatment was less efficient in the microbial reduction than the $\mathrm{SF}_{6}$ treatment, it reduced the total aflatoxin to $470 \mathrm{ng} / \mathrm{g}$. This result also shows the importance of oxidative species in aflatoxin degradation.

The reduction in the aflatoxin production of Aspergillus parasiticus and Aspergillus flavus, inoculated on groundnuts by low-pressure, CCP radio-frequency discharge (CCP $\mathrm{RF})$, was investigated by Devi et al. [76]. The discharge was generated in a glass reactor that was $120 \mathrm{~mm}$ high and had a $300 \mathrm{~mm}$ internal diameter equipped with two parallel electrodes of a $200 \mathrm{~mm}$ diameter placed at a $30 \mathrm{~mm}$ distance from each other. The working gas was $45 \%$ relative humidity air at 20 Pa pressure, while the input powers were $40 \mathrm{~W}$ and $60 \mathrm{~W}$ when the applied $13.56 \mathrm{MHz}$ voltages were 1500 and $1950 \mathrm{~V}$, respectively. The treatment of $10 \mathrm{~g}$ groundnuts at $40 \mathrm{~W}$ and $60 \mathrm{~W}$ resulted in a 2-log reduction in the initial spore load of $1.45 \times 10^{3} \mathrm{cfu} / \mathrm{g}$ within $30 \mathrm{~min}$ and $24 \mathrm{~min}$, respectively. A $97.9 \%$ and $99.3 \%$ reduction in the growth of Aspergillus parasiticus and Aspergillus flavus was found when treated at $60 \mathrm{~W}$ power. Due to the high humidity of the air used, the discharge is expected to provide a high concentration of highly reactive $\mathrm{OH}$ molecules, besides the reactive oxygen and nitrogen species supplied by an air plasma. Scanning electron microscopy (SEM) micrographs showed the complete disintegration of the fungal spore membrane due to the electroporation and etching caused by the plasma species. It was shown that the $40 \mathrm{~W} 15 \mathrm{~min}$ and the $60 \mathrm{~W} 12 \mathrm{~min}$ treatments reduced the original $0.35 \mu \mathrm{g} / \mathrm{kg} \mathrm{AFB}$ content of Aspergillus parasiticus-infected nuts by $70 \%$ and $90 \%$, respectively. Using the same treatments, in the Aspergillus flavus-infected nuts case, the original $9.84 \mu \mathrm{g} / \mathrm{kg} \mathrm{AFB}$ content was reduced by $65 \%$ and $95 \%$, respectively.

A new type of DBD of a large electrode gap designed around a polypropylene box was tested by Shi et al. $[77,78]$ for different humidity air-like $\mathrm{N}_{2} / \mathrm{O}_{2}$ and $\mathrm{O}_{2} / \mathrm{CO}_{2} / \mathrm{N}_{2}$ mixtures on plated aflatoxins and artificially aflatoxin-contaminated corn. The dimension of the box was $4.4 \mathrm{~cm} \times 18.4 \mathrm{~cm} \times 27.9 \mathrm{~cm}(\mathrm{H} \times \mathrm{W} \times \mathrm{L})$, and the two disc-shaped $158 \mathrm{~mm}$ diameter electrodes were placed on its top and bottom. The discharge was operated in $78 \% \mathrm{~N}_{2} / 22 \% \mathrm{O}_{2}$ (air) and $65 \% \mathrm{O}_{2} / 30 \% \mathrm{CO}_{2} / 5 \% \mathrm{~N}_{2}$ (modified air-MA) at $200 \mathrm{~W}$ and $50 \mathrm{~Hz}$ with $90 \mathrm{kV}$ voltage between the electrodes. Twenty-five grams of $\mathrm{AFB}_{1}$ spiked corn was treated with gases of relative humidity (RH) 5\%, 40\%, and $80 \%$, respectively, for 1 min to $30 \mathrm{~min}$, in the direct plasma or outside the direct plasma zone in the sealed box. The main species followed were ozone, $\mathrm{OH}$, and $\mathrm{NO}_{\mathrm{x}}$, which are believed to contribute to aflatoxin degradation. It was found that increasing the relative humidity resulted in a decrease in the ozone concentration in both types of gases. The ozone concentration reached a saturation level at about 10 min of discharge operation, namely at 5\% RH 17,500 ppm and 5250 ppm in the case of MA and air, respectively. Similar behavior was also observed for the $\mathrm{NO}_{\mathrm{x}}$ concentration that reached 12,250 ppm and $1650 \mathrm{ppm}$, respectively. Higher 
aflatoxin degradation was found at higher humidity, although the difference between the $40 \%$ and $80 \%$ RH gases was minimal. The initial aflatoxin level of $420 \mathrm{ng} / \mathrm{g}$ after $1 \mathrm{~min}$ and $10 \mathrm{~min}$ treatment with $40 \% \mathrm{RH}$ air decreased by $62 \%$ and $82 \%$, respectively. Slightly higher degradation was obtained using the MA gas mixture due to the higher $\mathrm{NO}_{\mathrm{x}}$ and ozone concentrations. The increase in the degradation efficiency with humidity was attributed to the creation of $\mathrm{OH}$ molecules in the humid gas discharge. A similar effect was observed in the case of ozonation by McDonough when using a humidified ozone [79]. The maximum $90 \%$ percentage of aflatoxin degradation was obtained with a $30 \mathrm{~min}$ treatment. It was established that stirring the seeds during treatment could significantly increase the efficiency of degradation, as could storing the seeds in the afterglow plasma for at least $24 \mathrm{~h}$. However, even these conditions could not achieve the 100\% aflatoxin decontamination of corn, suggesting that aflatoxin was also present within the kernel, which the plasma species could not reach. Moreover, no difference between the direct and indirect plasma treatments was found, suggesting the charged species did not play an essential role in the aflatoxin degradation. We note that in the case of artificially contaminated seeds, the aflatoxin contamination mainly occurs on the seeds' surface; yet, in naturally contaminated seeds the inside of the kernel is also infected.

Shi et al. [78] identified the degradation products of aflatoxins treated with the large gap $\mathrm{DBD}$ when treating $\mathrm{AFB}_{1}$ powder on a glass slide. The degradation products were identified by high performance liquid chromatography with time-of-flight mass spectrometry (HPLC-TOF-MS), and their structures were clarified via orbitrap mass spectrometry through fragmentation of the parental ions. Six main degradation products were observed: $\mathrm{C}_{16} \mathrm{H}_{16} \mathrm{O}_{6}, \mathrm{C}_{17} \mathrm{H}_{14} \mathrm{O}_{7}, \mathrm{C}_{14} \mathrm{H}_{12} \mathrm{O}_{5}, \mathrm{C}_{14} \mathrm{H}_{10} \mathrm{O}_{6}, \mathrm{C}_{17} \mathrm{H}_{12} \mathrm{O}_{7}$, and $\mathrm{C}_{19} \mathrm{H}_{18} \mathrm{O}_{8}$, which are different to those found by Wang et al. [70] with the treatment involving low-pressure CCP. Two of these degradation products, $\mathrm{C}_{16} \mathrm{H}_{16} \mathrm{O}_{6}$ and $\mathrm{C}_{17} \mathrm{H}_{14} \mathrm{O}_{7}$, were also identified as the products of $\mathrm{AFB}_{1}$ ozonolysis [80], suggesting that ozone is one of the main reactive species in this process. Overall, two degradation pathways of $\mathrm{AFB}_{1}$ by $\mathrm{DBD}$ treatment were proposed: one involving reactions with $\mathrm{H}, \mathrm{OH}$, and $\mathrm{CHO}$ radicals additions, the other involving epoxidation by $\mathrm{HO}_{2}$ radicals and oxidation by the combined effects of the oxidative species $\mathrm{OH}, \mathrm{H}_{2} \mathrm{O}_{2}$, and $\mathrm{O}_{3}$. It was suggested that the bioactivity of the plasma-treated $\mathrm{AFB}_{1}$ was significantly reduced following the disappearance of the C8-C9 double bond in the furofuran ring in all of the major degradation products, as well as the modification of the lactone ring, cyclopentanone, and the methoxyl group.

Table 1 presents a list of heavy molecules observed by different authors after $\mathrm{AFB}_{1}$ treatment with gaseous plasma. Many lighter molecules are volatile and have not been probed. The observed modifications are worthy of discussion given the general literature on plasma-surface engineering. First, it should be stressed that plasma treatments mainly cause modification of the surface's composition and structure. The same mechanism limits any bulk effects, as in the case of ozonation or ammoniation, diffusion. As long as the toxins are present on surfaces only, the interaction between the reactive plasma species and the organic material is extensive. Still, according to the relevant literature, the toxins may also be present inside the grains. The mold can attack kernels during all stages, from silking to maturity, preferentially colonizing the oil-rich germ tissue [81]. Therefore, plasma treatment is more efficient for destroying toxins synthesized by mold during improper storage rather than growth in the field. The concentration of toxins varies significantly among different constituents of a kernel. In one study, $\mathrm{AFB}_{1}$ was predominantly found in (or on the surface of) bran, where the concentration was ten times higher than the average of the corn seed [82]. In such cases, plasma treatment may be more efficient than other methods for destroying toxins. 
Table 1. Heavy molecules observed upon the treatment of aflatoxin $\mathrm{B}_{1}\left(\mathrm{C}_{17} \mathrm{H}_{12} \mathrm{O}_{6}\right)$ by discharge plasma.
$\mathrm{C}_{19} \mathrm{H}_{18} \mathrm{O}_{8}$
$\mathrm{C}_{17} \mathrm{H}_{17} \mathrm{O}_{9}$
$\mathrm{C}_{16} \mathrm{H}_{17} \mathrm{O}_{9}$
$\mathrm{C}_{14} \mathrm{H}_{12} \mathrm{O}_{5}$
$\mathrm{C}_{12} \mathrm{H}_{14} \mathrm{O}_{4}$
$\mathrm{C}_{17} \mathrm{H}_{14} \mathrm{O}_{7}$
$\mathrm{C}_{16} \mathrm{H}_{17} \mathrm{O}_{8}$
$\mathrm{C}_{16} \mathrm{H}_{16} \mathrm{O}_{6}$

Any interaction of gaseous plasma with organic molecules will bring at least two effects: (i) surface functionalization and (ii) etching. Besides, the UV and VUV radiation, or both, will cause structural modification of organic material through radiation damage [83].

The surface functionalization upon the treatment of organic material with a plasma sustained in a gas containing oxygen (such as air) occurs through the chemical bonding of reactive oxygen species to the carbon atoms of the organic matter. The functionalization leads to enrichment of the organic material surface with oxygen. With regard to Table 1 , the functionalization of aflatoxin by oxygen plasma treatment leads to partial functionalization with oxygen as products containing the same amount of carbon atoms (17 in the case of $\mathrm{AFB}_{1}$ ) contain more oxygen ( 7 or even 9 , compared to 6 for untreated $\mathrm{AFB}_{1}$ ). Apart from compounds containing $17 \mathrm{C}$-atoms, Table 1 also reveals several chemicals with $16 \mathrm{C}$ atoms only. The concentration of oxygen in these chemicals varies but is larger than the concentration in the untreated $\mathrm{AFB}_{1}$. The results summarized in Table 1 therefore confirm the functionalization of the original toxin with oxygen. Products with fewer carbon atoms were also detected, as shown in Table 1. Such products may be the remains of incomplete oxidation.

The etching of organic material coincides with surface activation. Many authors have determined the etching rates for simple organic matter, with the results varying. A typical etching rate for many polymers at room temperature is often of the order of nanometers per second [84]. The etching of organic matter sustained at the floating potential in weaklyionized highly reactive oxygen plasma is often explained by the complete oxidation of organic material upon treatment with plasma rich in reactive oxygen species. The reaction products of complete oxidation are $\mathrm{CO}_{2}$ and $\mathrm{H}_{2} \mathrm{O}$. These molecules are volatile and were not probed by the authors who reported that the toxins had been destroyed by gaseous plasma treatment. The technique was commercialized decades ago and is often called "plasma degreasing", "plasma stripping", "plasma ashing", or "discharge cleaning". Whatever the nomenclature, the oxygen plasma treatment was confirmed as an effective method for removing organic matter by oxidation. Yet, the oxidation might not always be complete. An intermediate stage involves the forming of various oxidized organic compounds that may be unstable and thus decay spontaneously well after the plasma treatment has been accomplished. The results in Table 1 reveal such incomplete oxidation: the formation of organic molecules with less carbon content than in the original toxin. Other molecules, such as aldehydes, ketones, and acids, are probably also formed upon the treatment of toxins but have not been probed by the authors of the scientific literature concerning the treatment of toxins by gaseous plasma. The science of plasma-toxin interaction is, therefore, still in its infancy, although the results summarized in this review hold promise with respect to the future application of this technique for purifying crops contaminated with toxins. The exact mechanisms at work in the plasma-oxidation of toxins are currently unknown and constitute a huge, tremendous scientific challenge.

Table 2 provides a summary of the gas discharge plasma decontamination of seeds from aflatoxin $\mathrm{B}_{1}$ and Aspergillus fungi. 
Table 2. Summary of the gas discharge plasma decontamination of seeds from aflatoxin B1 and Aspergillus fungi.

\begin{tabular}{|c|c|c|c|c|c|c|}
\hline System & $\begin{array}{l}\text { Inoculated } \\
\text { Seeds }\end{array}$ & Quantity & $\begin{array}{l}\text { Treatment } \\
\text { Time }\end{array}$ & $\begin{array}{l}\text { Input } \\
\text { Power }\end{array}$ & $\begin{array}{c}\text { Initial AFB } 1 \\
\text { Concentration }\end{array}$ & Reduction \\
\hline $\mathrm{N}_{2} \mathrm{DBD}[71]$ & hazelnut & $40 \mathrm{~g}$ & $12 \mathrm{~min}$ & $1150 \mathrm{~W}$ & $20 \mathrm{ng} / \mathrm{g}$ & $70 \%$ \\
\hline air ICP [75] & hazelnut & $8 \mathrm{~g}$ & $20 \mathrm{~min}$ & $300 \mathrm{~W}$ & $950 \mathrm{ng} / \mathrm{g}$ & $50 \%$ \\
\hline $45 \%$ RH air CCP [76] & groundnuts & $10 \mathrm{~g}$ & $12 \mathrm{~min}$ & $60 \mathrm{~W}$ & $9.84 \mathrm{ng} / \mathrm{g}$ & $95 \%$ \\
\hline \multirow[t]{3}{*}{$40 \%$ RH air DBD [77] } & corn & $25 \mathrm{~g}$ & $1 \mathrm{~min}$ & $200 \mathrm{~W}$ & $420 \mathrm{ng} / \mathrm{g}$ & $62 \%$ \\
\hline & & & $10 \mathrm{~min}$ & & & $82 \%$ \\
\hline & & & $30 \mathrm{~min}$ & & & $90 \%$ \\
\hline air RF jet [73] & maize & $40 \mathrm{~g}$ & $5 \mathrm{~min}$ & $655 \mathrm{~W}$ & $10^{7} \mathrm{cfu} / \mathrm{g}$ & $5 \log$ \\
\hline air ICP [74] & maize & $8 \mathrm{~g}$ & $20 \mathrm{~min}$ & $300 \mathrm{~W}$ & $5 \times 10^{6} \mathrm{cfu} / \mathrm{g}$ & $1 \log$ \\
\hline $45 \%$ RH air CCP [76] & groundnuts & $10 \mathrm{~g}$ & $24 \mathrm{~min}$ & $60 \mathrm{~W}$ & $1.45 \times 10^{3} \mathrm{cfu} / \mathrm{g}$ & $2 \log$ \\
\hline
\end{tabular}

\section{Main Points and Future Perspectives}

Although the methods for destroying aflatoxins have been reviewed in this paper, different authors have unfortunately used different experimental setups, making the results hardly comparable. Still, one can draw the following conclusions:

1. The destruction of toxins remains both a scientific and technological challenge.

2. The reported treatment times are prohibitively long for industrial application.

3. The incomplete description of the particularities of the experimental setups and treatment conditions prevents valuable conclusions from being drawn.

4. The plasma methods seem promising, but upscaling poses a significant challenge.

Despite the incomparability of the different authors' results, we present the correlations in Figure 5. Three diagrams are plotted for the $\mathrm{AFB}_{1}$ decontamination: the reported degradation efficiency (i) versus treatment time (Figure 5a), (ii) versus treatment time divided by the contamination rate (Figure $5 b$ ), and (iii) versus treatment time divided by the product of the contamination rate and mass of the sample (Figure 5c).

While different pathways of toxin destruction have been proposed and evaluated by several authors, it is generally concluded that the chemical reactions mainly occur on the surface of the material composed of or containing toxins as the diffusion of active species into the bulk material is limited. Furthermore, the rates of the chemical reactions increase with temperature, while the detoxification rates depend on the flux of reactants onto the surface. From this point of view, the high-pressure gaseous treatments at elevated temperatures are preferable. Such treatments are, of course, limited to the heat the seeds can withstand. A good example is ammoniation, where efficiency increases with pressure and temperature. Although the treatment times are long (see Figure 5a), this method can be applied in the case of large storage containers where long treatment times (measured in days, even weeks) are feasible to allow for the diffusion of the ammonia (Figure 5c).

The ozonation is also limited by diffusion (requiring long treatment times; Figure 5a). However, in this case the degradation results in volatile products, which ensure the low reversibility of the process. The oxidation of toxins is therefore more efficient than ammoniation. Yet, the available ozone concentration limits the flux of ozone molecules onto the surface of samples contaminated with toxins. Another problem with ozonation is poor selectivity: the ozone molecules will not only interact with the toxins but with many other materials, including the grains themselves. This means that the expenditure for ozone production may be too high for commercial applications.

Ultraviolet radiation remains a promising technique for the destruction of toxins, but the relevant literature does not reveal the influence of photon energy. Photons are likely to penetrate quite deep into the organic matter and thus this technique is not limited to surface effects. The penetration depth depends enormously on the photon energy (or the UV radiation wavelength). Low-energy UV photons (such as those from mediumpressure mercury lamps) penetrate deep into the organic matter, stimulate photo-oxidation, photo-degradation, and photo-elimination (or both), which was found beneficial for the 
degradation of aflatoxins. Not much research has been performed on the degradation of toxins using high-energy photons.
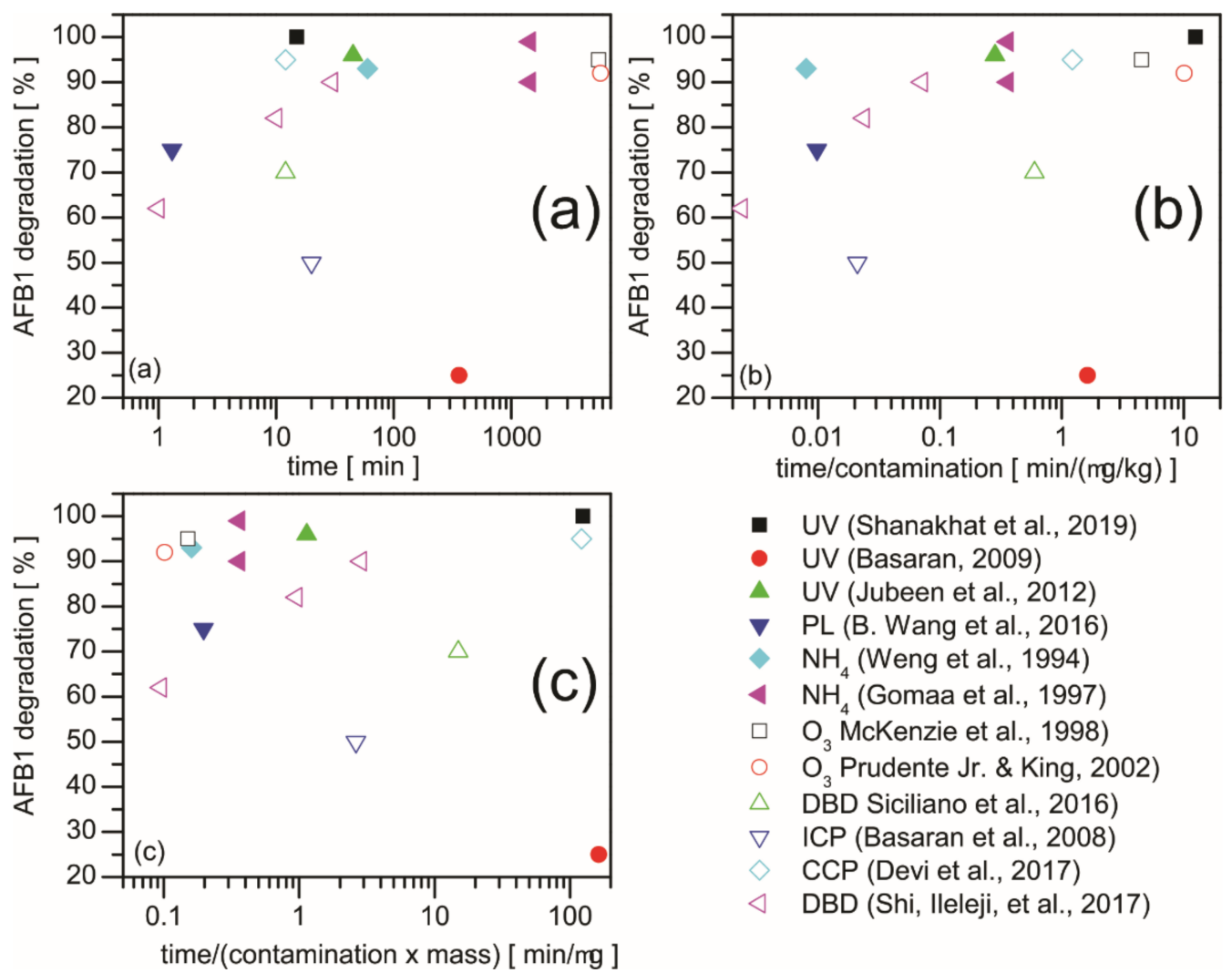

- UV (Shanakhat et al., 2019)

- UV (Basaran, 2009)

A UV (Jubeen et al., 2012)

$\nabla$ PL (B. Wang et al., 2016)

$\mathrm{NH}_{4}$ (Weng et al., 1994)

$4 \mathrm{NH}_{4}$ (Gomaa et al., 1997)

$\square \quad O_{3}$ McKenzie et al., 1998)

O Prudente Jr. \& King, 2002)

$\triangle$ DBD Siciliano et al., 2016)

$\nabla \quad$ ICP (Basaran et al., 2008)

CCP (Devi et al., 2017)

$\triangleleft$ DBD (Shi, lleleji, et al., 2017)

Figure 5. $\mathrm{AFB}_{1}$ degradation efficiency versus (a) treatment time in min, (b) time/contamination in $\mathrm{min} /(\mathrm{mg} / \mathrm{kg})$, and (c) time/contamination $\times$ mass) in $\mathrm{min} / \mathrm{kg}$ achieved with different methods and contaminated samples. UV and pulsed light treatments are presented for artificially contaminated $100 \mathrm{~g}$ of semolina [19], $8 \mathrm{~g}$ of hazelnut [20], $250 \mathrm{~g}$ of nuts [21], and $50 \mathrm{~g}$ of rice [23]. Ammoniation experiments were conducted on $50 \mathrm{~g}$ of grounded naturally contaminated corn [29] and $1 \mathrm{~kg}$ of artificially infected corn [30]. The greatest efficiency was achieved with the high-pressure hightemperature (HP/HT) method. Ozonation results are presented for $30 \mathrm{~kg}$ [32] and $100 \mathrm{~kg}$ [35] of naturally contaminated corn. The gas discharge plasma treatments were performed with $40 \mathrm{~g}$ of hazelnut [71], $8 \mathrm{~g}$ of hazelnut [75], $10 \mathrm{~g}$ of groundnut [76], and $25 \mathrm{~g}$ of corn [77]. For the treatment details, see the related sections in this paper.

Gas discharge plasmas hold considerable potential for detoxifying agricultural products. Plasmas contain reactive species of oxidation potential exceeding the potential of ozone and may also be a significant source of UV radiation, depending on the discharge configuration. Both low-pressure and atmospheric discharges were used for the destruction of toxins. Unfortunately, the authors did not report the fluxes of reactive plasma species of high oxidation potential onto the sample surfaces, meaning it is impossible to compare their results with those obtained for ozone. The reactive species with high oxidation potential likely to be found in gaseous plasma sustained in the air include the O-atoms (in both the ground and metastable states), the NO molecules, and the $\mathrm{N}$-atoms. Their density in non-equilibrium gas discharge plasmas is limited either by gas-phase or surface effects. Still, their production is energetically beneficial as, in such discharges, a significant part of the available discharge power is spent on dissociation. While the relatively short treatment times needed for efficient detoxification using gas discharge plasma (Figure 5) are encouraging, more systematic work with well-characterized plasmas should be performed. The available scientific works on plasma techniques reviewed in this paper are limited to 
academic research using a small mass of samples and relatively weak contamination. This means the systems need to be scaled up to make the plasma technique competitive.

Author Contributions: Conceptualization, K.K., G.P. and M.M.; methodology, K.K., R.Z. and N.R.; validation, G.P., M.M. and P.G.; formal analysis, K.K. and N.R.; investigation, K.K. and R.Z.; resources, P.G.; data curation, M.K.; writing—original draft preparation, K.K., G.P. and M.M.; writing—review and editing, G.P. and N.R.; visualization, K.K., R.Z. and M.K.; supervision, G.P.; project administration, P.G. and M.K.; funding acquisition, P.G. and M.M. All authors have read and agreed to the published version of the manuscript.

Funding: This research was funded by the EU Regional Development Fund and the Ministry of Education, Science and Sport, project Plasma Seed Treatment [contract \#C3330-18-952005].

Informed Consent Statement: Not applicable.

Acknowledgments: This work was supported by the EU Regional Development Fund and the Ministry of Education, Science and Sport of Slovenia, the project "Plasma Seed Treatment" [contract \#C3330-18-952005].

Conflicts of Interest: The authors declare no conflict of interest.

\section{References}

1. Varga, J.; Tóth, B. Novel strategies to control mycotoxins in feeds: A review. Acta Vet. Hung. 2005, 53, 189-203. [CrossRef]

2. Marchese, S.; Polo, A.; Ariano, A.; Velotto, S.; Costantini, S.; Severino, L. Aflatoxin B1 and M1: Biological Properties and Their Involvement in Cancer Development. Toxins 2018, 10, 214. [CrossRef] [PubMed]

3. Baranyi, N.; Kocsubé, S.; Vágvölgyi, C.; Varga, J. Current trends in aflatoxin research. Acta Biol. Szeged. 2013, 57, 95-107.

4. Veldman, A.; Meijs, J.A.C.; Borggreve, G.J.; Heeres-van der Tol, J.J. Carry-over of aflatoxin from cows' food to milk. Anim. Sci. 1992, 55, 163-168. [CrossRef]

5. Prandini, A.; Tansini, G.; Sigolo, S.; Filippi, L.; Laporta, M.; Piva, G. On the occurrence of aflatoxin M1 in milk and dairy products. Food Chem. Toxicol. 2009, 47, 984-991. [CrossRef] [PubMed]

6. Guo, Y.; Zhao, L.; Ma, Q.; Ji, C. Novel strategies for degradation of aflatoxins in food and feed: A review. Food Res. Int. 2021, 140, 109878. [CrossRef]

7. Guengerich, F.P.; Johnson, W.W.; Shimada, T.; Ueng, Y.-F.; Yamazaki, H.; Langouët, S. Activation and detoxication of aflatoxin B1. Mutat. Res. Mol. Mech. Mutagen. 1998, 402, 121-128. [CrossRef]

8. Neal, G.E.; Eaton, D.L.; Judah, D.J.; Verma, A. Metabolism and toxicity of aflatoxins M1 and B1 in human-derived in vitro systems. Toxicol. Appl. Pharmacol. 1998, 151, 152-158. [CrossRef] [PubMed]

9. Wild, C.P. The toxicology of aflatoxins as a basis for public health decisions. Mutagenesis 2002, 17, 471-481. [CrossRef]

10. Liu, Y.; Wang, W. Aflatoxin B1 impairs mitochondrial functions, activates ROS generation, induces apoptosis and involves Nrf2 signal pathway in primary broiler hepatocytes. Anim. Sci. J. 2016, 87, 1490-1500. [CrossRef] [PubMed]

11. MdQuadri, S.H.; Niranjan, M.S.; Chaluvaraju, K.C.; Shantaram, U.; Enamul, H.Y.S.M. An overview on chemistry, toxicity, analysis and control of aflatoxins. Int. J. Chem. Life Sci. 2013, 2, 1071-1078.

12. Jard, G.; Liboz, T.; Mathieu, F.; Guyonvarc'h, A.; Lebrihi, A. Review of mycotoxin reduction in food and feed: From prevention in the field to detoxification by adsorption or transformation. Food Addit. Contam. Part A 2011, 28, 1590-1609. [CrossRef]

13. Pankaj, S.K.; Shi, H.; Keener, K.M. A review of novel physical and chemical decontamination technologies for aflatoxin in food. Trends Food Sci. Technol. 2018, 71, 73-83. [CrossRef]

14. Samarajeewa, U.; Sen, A.C.; Cohen, M.D.; Wei, C.I. Detoxification of aflatoxins in foods and feeds by physical and chemical methods. J. Food Prot. 1990, 53, 489-501. [CrossRef] [PubMed]

15. Yousef, A.E.; Marth, E.H. Kinetics of interaction of aflatoxin M1 in aqueous solutions irradiated with ultraviolet energy. J. Agric. Food Chem. 1987, 35, 785-789. [CrossRef]

16. Liu, R.; Jin, Q.; Tao, G.; Shan, L.; Huang, J.; Liu, Y.; Wang, X.; Mao, W.; Wang, S. Photodegradation kinetics and byproducts identification of the aflatoxin B1 in aqueous medium by ultra-performance liquid chromatography-quadrupole time-of-flight mass spectrometry. J. Mass Spectrom. 2010, 45, 553-559. [CrossRef]

17. Patras, A.; Julakanti, S.; Yannam, S.; Bansode, R.R.; Burns, M.; Vergne, M.J. Effect of UV irradiation on aflatoxin reduction: A cytotoxicity evaluation study using human hepatoma cell line. Mycotoxin Res. 2017, 33, 343-350. [CrossRef] [PubMed]

18. Atalla, M.M.; Hassanein, N.M.; El-Beih, A.A.; Youssef, Y.A. Effect of fluorescent and UV light on mycotoxin production under different relative humidities in wheat grains. Acta Pharm. Turc. 2004, 46, 205-222.

19. Shanakhat, H.; Sorrentino, A.; Raiola, A.; Reverberi, M.; Salustri, M.; Masi, P.; Cavella, S. Technological properties of durum wheat semolina treated by heating and UV irradiation for reduction of mycotoxin content. J. Food Process Eng. 2019, 42 , e13006. [CrossRef]

20. Basaran, P. Reduction of Aspergillus parasiticus on hazelnut surface by UV-C treatment. Int. J. Food Sci. Technol. 2009, 44, 1857-1863. [CrossRef] 
21. Jubeen, F.; Bhatti, I.A.; Khan, M.Z.; Zahoor-Ul, H.; Shahid, M. Effect of UVC irradiation on aflatoxins in ground nut (Arachis hypogea) and tree nuts (Juglans regia, prunus duclus and pistachio vera). J. Chem. Soc. Pakistan 2012, 34, 1366-1374.

22. Moreau, M.; Lescure, G.; Agoulon, A.; Svinareff, P.; Orange, N.; Feuilloley, M. Application of the pulsed light technology to mycotoxin degradation and inactivation. J. Appl. Toxicol. 2013, 33, 357-363. [CrossRef]

23. Wang, B.; Mahoney, N.E.; Pan, Z.; Khir, R.; Wu, B.; Ma, H.; Zhao, L. Effectiveness of pulsed light treatment for degradation and detoxification of aflatoxin B1 and B2 in rough rice and rice bran. Food Control 2016, 59, 461-467. [CrossRef]

24. Park, D.L.; Price, W.D. Reduction of aflatoxin hazards using ammoniation. Rev. Environ. Contam. Toxicol. 2001, 171, 139-176.

25. Schroeder, T.; Zweifel, U.; Sagelsdorff, P.; Friederich, U.; Luethy, J.; Schlatter, C. Ammoniation of aflatoxin-containing corn: Distribution, in vivo covalent deoxyribonucleic acid binding, and mutagenicity of reaction products. J. Agric. Food Chem. 1985, 33, 311-316. [CrossRef]

26. Cucullu, A.F.; Lee, L.S.; Pons, W.A.; Stanley, J.B. Ammoniation of aflatoxin B1. Isolation and characterization of a product with molecular weight 206. J. Agric. Food Chem. 1976, 24, 408-410. [CrossRef]

27. Lee, L.S.; Stanley, J.B.; Cucullu, A.F.; Pons, W.A.J.; Goldblatt, L.A. Ammoniation of aflatoxin B1: Isolation and identification of the major reaction product. J. Assoc. Off. Anal. Chem. 1974, 57, 626. [CrossRef] [PubMed]

28. Martinez, A.J.; Weng, C.Y.; Park, D.L. Distribution of ammonia/aflatoxin reaction products in corn following exposure to ammonia decontamination procedure. Food Addit. Contam. 1994, 11, 659-667. [CrossRef] [PubMed]

29. Weng, C.Y.; Martinez, A.J.; Park, D.L. Efficacy and permanency of ammonia treatment in reducing aflatoxin levels in corn. Food Addit. Contam. 1994, 11, 649-658. [CrossRef] [PubMed]

30. Gomaa, M.N.E.; Ayesh, A.M.; Abdel Galil, M.M.; Naguib, K. Effect of high pressure ammoniation procedure on the detoxification of aflatoxins. Mycotoxin Res. 1997, 13, 23-34. [CrossRef]

31. Norred, W.P. Ammonia treatment to destroy aflatoxins in corn. J. Food Prot. 1982, 45, 972-976. [CrossRef]

32. McKenzie, K.S.; Kubena, L.F.; Denvir, A.J.; Rogers, T.D.; Hitchens, G.D.; Bailey, R.H.; Harvey, R.B.; Buckley, S.A.; Phillips, T.D. Aflatoxicosis in turkey poults is prevented by treatment of naturally contaminated corn with ozone generated by electrolysis. Poult. Sci. 1998, 77, 1094-1102. [CrossRef] [PubMed]

33. McKenzie, K.S.; Sarr, A.B.; Mayura, K.; Bailey, R.H.; Miller, D.R.; Rogers, T.D.; Norred, W.P.; Voss, K.A.; Plattner, R.D.; Kubena, L.F.; et al. Oxidative degradation and detoxification of mycotoxins using a novel source of ozone. Food Chem. Toxicol. 1997, 35, 807-820. [CrossRef]

34. Luo, X.; Wang, R.; Wang, L.; Li, Y.; Bian, Y.; Chen, Z. Effect of ozone treatment on aflatoxin B1 and safety evaluation of ozonized corn. Food Control 2014, 37, 171-176. [CrossRef]

35. Prudente, A.D., Jr.; King, J.M. Efficacy and safety evaluation of ozonation to degrade aflatoxin in corn. J. Food Sci. 2002, 67, 2866-2872. [CrossRef]

36. Proctor, A.D.; Ahmedna, M.; Kumar, J.V.; Goktepe, I. Degradation of aflatoxins in peanut kernels/flour by gaseous ozonation and mild heat treatment. Food Addit. Contam. 2004, 21, 786-793. [CrossRef]

37. Ta, E.-D.; Ama, S.; El-Desouky, A.I.; Ha, E.-M. Effect of ozone gas on degradation of aflatoxin B1 and Aspergillus Flavus fungal. J. Environ. Anal. Toxicol. 2012, 2, 128. [CrossRef]

38. Allen, B.; $\mathrm{Wu}, \mathrm{J} . ;$ Doan, H. Inactivation of fungi associated with barley grain by gaseous ozone. J. Environ. Sci. Health Part B 2003, 38, 617-630. [CrossRef]

39. Savi, G.D.; Piacentini, K.C.; Bittencourt, K.O.; Scussel, V.M. Ozone treatment efficiency on Fusarium graminearum and deoxynivalenol degradation and its effects on whole wheat grains (Triticum aestivum L.) quality and germination. J. Stored Prod. Res. 2014, 59, 245-253. [CrossRef]

40. Kells, S.A.; Mason, L.J.; Maier, D.E.; Woloshuk, C.P. Efficacy and fumigation characteristics of ozone in stored maize. J. Stored Prod. Res. 2001, 37, 371-382. [CrossRef]

41. Liebermann, M.A.; Lichtenberg, A.J. Principles of Plasma Discharges and Materials Processing, 1st ed.; John Wiley \& Sons, Inc.: New York, NY, USA, 1994; ISBN 0-471-00577-0.

42. Eremin, D.; Bienholz, S.; Szeremley, D.; Trieschmann, J.; Ries, S.; Awakowicz, P.; Mussenbrock, T.; Brinkmann, R.P. On the physics of a large CCP discharge. Plasma Sources Sci. Technol. 2016, 25, 025020. [CrossRef]

43. Mozetič, M.; Primc, G.; Vesel, A.; Zaplotnik, R.; Modic, M.; Junkar, I.; Recek, N.; Klanjšek-Gunde, M.; Guhy, L.; Sunkara, M.K.M.K.; et al. Application of extremely non-equilibrium plasmas in the processing of nano and biomedical materials. Plasma Sources Sci. Technol. 2015, 24, 015026. [CrossRef]

44. Kutasi, K.; Saoudi, B.; Pintassilgo, C.D.; Loureiro, J.; Moisan, M. Modelling the Low-Pressure $\mathrm{N}_{2}-\mathrm{O}_{2}$ Plasma Afterglow to Determine the Kinetic Mechanisms Controlling the UV Emission Intensity and Its Spatial Distribution for Achieving an Efficient Sterilization Process. Plasma Process. Polym. 2008, 5, 840-852. [CrossRef]

45. Moisan, M.; Boudam, K.; Carignan, D.; Kéroack, D.; Levif, P.; Barbeau, J.; Séguin, J.; Kutasi, K.; Elmoualij, B.; Thellin, O.; et al. Sterilization/disinfection of medical devices using plasma: The flowing afterglow of the reduced-pressure $\mathrm{N}_{2}-\mathrm{O}_{2}$ discharge as the inactivating medium. Eur. Phys. J. Appl. Phys. 2013, 63, 10001. [CrossRef]

46. Nagatsu, M.; Terashita, F.; Koide, Y. Low-Temperature Sterilization with Surface-Wave-Excited Oxygen Plasma. Jpn. J. Appl. Phys. 2003, 42, L856-L859. [CrossRef]

47. Fridman, A.; Chirokov, A.; Gutsol, A. Non-thermal atmospheric pressure discharges. J. Phys. D Appl. Phys. 2005, 38, R1-R24. [CrossRef] 
48. Kogelschatz, U. Dielectric-barrier discharges: Their History, Discharge Physics, and Industrial Applications. Plasma Chem. Plasma Process. 2003, 23, 1-46. [CrossRef]

49. Šimor, M.; Ráhel', J.; Vojtek, P.; Černák, M.; Brablec, A. Atmospheric-pressure diffuse coplanar surface discharge for surface treatments. Appl. Phys. Lett. 2002, 81, 2716-2718. [CrossRef]

50. Černák, M.; Černáková, L.; Hudec, I.; Kováčik, D.; Zahoranová, A. Diffuse Coplanar Surface Barrier Discharge and its applications for in-line processing of low-added-value materials. Eur. Phys. J. Appl. Phys. 2009, 47, 22806. [CrossRef]

51. Winter, J.; Brandenburg, R.; Weltmann, K.-D. Atmospheric pressure plasma jets: An overview of devices and new directions. Plasma Sources Sci. Technol. 2015, 24, 064001. [CrossRef]

52. Puač, N.; Gherardi, M.; Shiratani, M. Plasma agriculture: A rapidly emerging field. Plasma Process. Polym. 2018, 15, 1700174. [CrossRef]

53. Laroussi, M. Nonthermal decontamination of biological media by atmospheric-pressure plasmas: Review, analysis, and prospects. IEEE Trans. Plasma Sci. 2002, 30, 1409-1415. [CrossRef]

54. Isbary, G.; Stolz, W.; Shimizu, T.; Monetti, R.; Bunk, W.; Schmidt, H.-U.; Morfill, G.E.; Klämpfl, T.G.; Steffes, B.; Thomas, H.M.; et al. Cold atmospheric argon plasma treatment may accelerate wound healing in chronic wounds: Results of an open retrospective randomized controlled study in vivo. Clin. Plasma Med. 2013, 1, 25-30. [CrossRef]

55. Bermúdez-Aguirre, D.; Wemlinger, E.; Pedrow, P.; Barbosa-Cánovas, G.; Garcia-Perez, M. Effect of atmospheric pressure cold plasma (APCP) on the inactivation of Escherichia coli in fresh produce. Food Control 2013, 34, 149-157. [CrossRef]

56. Volin, J.C.; Denes, F.S.; Young, R.A.; Park, S.M.T. Modification of Seed Germination Performance through Cold Plasma Chemistry Technology. Crop Sci. 2000, 40, 1706-1718. [CrossRef]

57. Dobrin, D.; Magureanu, M.; Mandache, N.B.; Ionita, M.-D. The effect of non-thermal plasma treatment on wheat germination and early growth. Innov. Food Sci. Emerg. Technol. 2015, 29, 255-260. [CrossRef]

58. Bethke, P.; Gubler, F.; Jacobsen, J.; Jones, R. Dormancy of Arabidopsis seeds and barley grains can be broken by nitric oxide. Planta 2004, 219, 847-855. [CrossRef]

59. Ma, Z.; Marsolais, F.; Bykova, N.V.; Igamberdiev, A.U. Nitric Oxide and Reactive Oxygen Species Mediate Metabolic Changes in Barley Seed Embryo during Germination. Front. Plant Sci. 2016, 7. [CrossRef]

60. Brasoveanu, M.; Nemţanu, M.; Carmen, S.-B.; Karaca, G.; Erper, İ. Effect of Glow Discharge Plasma on Germination and Fungal Load of some Cereal Seeds. Rom. Rep. Phys. 2015, 67.

61. Jiang, J.; He, X.; Li, L.; Li, J.; Shao, H.; Xu, Q.; Ye, R.; Dong, Y. Effect of Cold Plasma Treatment on Seed Germination and Growth of Wheat. Plasma Sci. Technol. 2014, 16, 54-58. [CrossRef]

62. Sera, B.; Spatenka, P.; Sery, M.; Vrchotova, N.; Hruskova, I. Influence of Plasma Treatment on Wheat and Oat Germination and Early Growth. IEEE Trans. Plasma Sci. 2010, 38, 2963-2968. [CrossRef]

63. Szőke, C.; Nagy, Z.; Gierczik, K.; Székely, A.; Spitkól, T.; Zsuboril, Z.T.; Galiba, G.; Marton, C.L.; Kutasi, K. Effect of the afterglows of low pressure $\mathrm{Ar} / \mathrm{N}_{2}-\mathrm{O}_{2}$ surface-wave microwave discharges on barley and maize seeds. Plasma Process. Polym. 2018, 15, 1700138. [CrossRef]

64. Zahoranová, A.; Henselová, M.; Hudecová, D.; Kaliňáková, B.; Kováčik, D.; Medvecká, V.; Černák, M. Effect of Cold Atmospheric Pressure Plasma on the Wheat Seedlings Vigor and on the Inactivation of Microorganisms on the Seeds Surface. Plasma Chem. Plasma Process. 2016, 36, 397-414. [CrossRef]

65. Rossi, F.; Kylián, O.; Rauscher, H.; Hasiwa, M.; Gilliland, D. Low pressure plasma discharges for the sterilization and decontamination of surfaces. New J. Phys. 2009, 11, 115017. [CrossRef]

66. Raballand, V.; Benedikt, J.; Wunderlich, J.; von Keudell, A. Inactivation of Bacillus atrophaeus and of Aspergillus niger using beams of argon ions, of oxygen molecules and of oxygen atoms. J. Phys. D Appl. Phys. 2008, 41, 115207. [CrossRef]

67. Philip, N.; Saoudi, B.; Crevier, M.-C.; Moisan, M.; Barbeau, J.; Pelletier, J. The respective roles of UV photons and oxygen atoms in plasma sterilization at reduced gas pressure: The case of N2-O2 mixtures. IEEE Trans. Plasma Sci. 2002, 30, 1429-1436. [CrossRef]

68. Wacoo, A.P.; Wendiro, D.; Vuzi, P.C.; Hawumba, J.F. Methods for Detection of Aflatoxins in Agricultural Food Crops. J. Appl. Chem. 2014, 2014, 1-15. [CrossRef]

69. Park, B.J.; Takatori, K.; Sugita-Konishi, Y.; Kim, I.-H.; Lee, M.-H.; Han, D.-W.; Chung, K.-H.; Hyun, S.O.; Park, J.-C. Degradation of mycotoxins using microwave-induced argon plasma at atmospheric pressure. Surf. Coat. Technol. 2007, 201, 5733-5737. [CrossRef]

70. Wang, S.-Q.; Huang, G.-Q.; Li, Y.-P.; Xiao, J.-X.; Zhang, Y.; Jiang, W.-L. Degradation of aflatoxin B1 by low-temperature radio frequency plasma and degradation product elucidation. Eur. Food Res. Technol. 2015, 241, 103-113. [CrossRef]

71. Siciliano, I.; Spadaro, D.; Prelle, A.; Vallauri, D.; Cavallero, M.; Garibaldi, A.; Gullino, M. Use of cold atmospheric plasma to detoxify hazelnuts from aflatoxins. Toxins 2016, 8, 125. [CrossRef]

72. Kutasi, K.; Popović, D.; Krstulović, N.; Milošević, S. Tuning the composition of plasma-activated water by a surface-wave microwave discharge and a kHz plasma jet. Plasma Sources Sci. Technol. 2019, 28, 095010. [CrossRef]

73. Dasan, B.G.; Boyaci, I.H.; Mutlu, M. Inactivation of aflatoxigenic fungi (Aspergillus spp.) on granular food model, maize, in an atmospheric pressure fluidized bed plasma system. Food Control 2016, 70, 1-8. [CrossRef]

74. Selcuk, M.; Oksuz, L.; Basaran, P. Decontamination of grains and legumes infected with Aspergillus spp. and Penicillum spp. by cold plasma treatment. Bioresour. Technol. 2008, 99, 5104-5109. [CrossRef] [PubMed]

75. Basaran, P.; Basaran-Akgul, N.; Oksuz, L. Elimination of Aspergillus parasiticus from nut surface with low pressure cold plasma (LPCP) treatment. Food Microbiol. 2008, 25, 626-632. [CrossRef] 
76. Devi, Y.; Thirumdas, R.; Sarangapani, C.; Deshmukh, R.R.; Annapure, U.S. Influence of cold plasma on fungal growth and aflatoxins production on groundnuts. Food Control 2017, 77, 187-191. [CrossRef]

77. Shi, H.; Ileleji, K.; Stroshine, R.L.; Keener, K.; Jensen, J.L. Reduction of aflatoxin in corn by high voltage atmospheric cold plasma. Food Bioprocess Technol. 2017, 10, 1042-1052. [CrossRef]

78. Shi, H.; Cooper, B.; Stroshine, R.L.; Ileleji, K.E.; Keener, K.M. Structures of degradation products and degradation pathways of aflatoxin B1 by high-voltage atmospheric cold plasma (HVACP) treatment. J. Agric. Food Chem. 2017, 65, 6222-6230. [CrossRef] [PubMed]

79. McDonough, M.X.; Campabadal, C.A.; Mason, L.J.; Maier, D.E.; Denvir, A.; Woloshuk, C. Ozone application in a modified screw conveyor to treat grain for insect pests, fungal contaminants, and mycotoxins. J. Stored Prod. Res. 2011, 47, 249-254. [CrossRef]

80. Luo, X.; Wang, R.; Wang, L.; Wang, Y.; Chen, Z. Structure elucidation and toxicity analyses of the degradation products of aflatoxin B1 by aqueous ozone. Food Control 2013, 31, 331-336. [CrossRef]

81. Dolezal, A.L.; Shu, X.; OBrian, G.R.; Nielsen, D.M.; Woloshuk, C.P.; Boston, R.S.; Payne, G.A. Aspergillus flavus infection induces transcriptional and physical changes in developing maize kernels. Front. Microbiol. 2014, 5. [CrossRef]

82. Brera, C.; Catano, C.; de Santis, B.; Debegnach, F.; de Giacomo, M.; Pannunzi, E.; Miraglia, M. Effect of industrial processing on the distribution of aflatoxins and zearalenone in corn-milling fractions. J. Agric. Food Chem. 2006, 54, 5014-5019. [CrossRef] [PubMed]

83. Vesel, A.; Primc, G.; Zaplotnik, R.; Mozetič, M. Applications of highly non-equilibrium low-pressure oxygen plasma for treatment of polymers and polymer composites on an industrial scale. Plasma Phys. Control. Fusion 2020, 62, 024008. [CrossRef]

84. Vesel, A.; Mozetic, M. New developments in surface functionalization of polymers using controlled plasma treatments. J. Phys. D Appl. Phys. 2017, 50, 293001. [CrossRef] 